\title{
On measuring and decomposing inequality of opportunity in access to health services among Tunisian children: a new approach for public policy
}

\author{
Anis Saidi ${ }^{i^{*}}$ and Mekki Hamdaoui ${ }^{2}$
}

\begin{abstract}
Background: The early years in children's life are the key to physical, cognitive-language, and, socio-emotional skills development. So, it is of paramount importance in this period to be interested in different indicators that would influence the child's health.

Methods: This paper measures inequality of opportunities among Tunisian children concerning access to nutritional and healthy services using Human Opportunity-Index and Shapely decomposition methods.

Results: Many disparities between regions have been detected since 1982 until 2012. Tunisian children face unequal opportunities to develop in terms of health, nutrition, cognitive, social, and emotional development. Likewise, we found that, parents' education, wealth, age of household head and geographic factors as key factors determining child development outcomes.

Conclusion: Our findings suggested that childhood unequal opportunities in Tunisia are explained by pension funds deficiency and structural problem in the labor market.
\end{abstract}

Trial registration: The results of a health care intervention on human participants "retrospectively registered".

Keywords: Inequality of opportunity, Dissimilarity index, Tunisia, Children

JEL classification: D63, D30

\section{Background}

World Development Organizations seek to reduce the proportion of people who suffer from hunger. A reduction in the prevalence of malnutrition can contribute to the reduction of infant mortality. However, countries tend to under-invest in this stage of development, particularly in developing countries. Inequality of opportunity in early childhood is studied across the early life course and is often quantified until age five in terms of health, nutrition, social-emotional development, early learning, and early work and

\footnotetext{
* Correspondence: anis.saidi111@gmail.com

${ }^{1}$ Faculty of Economic Sciences and Management of Sousse (FSEGSousse),

Sousse, Tunisia

Full list of author information is available at the end of the article
}

explained by many circumstances such us access to health services.

Likewise, a reduced regional disparity is an important determinant of long run growth and development and contributes to guarantee political and economical stability. Furthermore, variation in disease environments could contribute to inequality in health outcomes related to place of residence [1].

Despite the importance of early childhood, there is limited research on the state of early childhood development and inequality in Tunisia. This issue is frequently absent from political agendas, insufficiently researched, and under-resourced. In this paper, we 
examine the inequality of opportunity that children in Tunisia face in early childhood across a variety of basic services access and decompose inequality of opportunity in order to identify its determinants. This analysis not only contributes to the improvement of limited research on early children development and inequality in Tunisia, but also provides critical information for identifying the vulnerable groups, key issues, and factors that limit children's development early in life. Our contribution is to take into consideration multidimensional aspects of inequality to overcome shortcomings linked to previous one-dimensional methodology.

Equality of opportunity is based on the distinction between efforts and circumstances that are under and beyond the individual's control $[1,2]$. So unequal opportunities result from a big difference in circumstances such as: family background sex, place of birth... the ways of dealing with such circumstances have being unfair and require quick and efficient action from political decision makers. Constraints on access to services and basis resources contribute to perpetuate the lack of both capacities and opportunities in a large part of society $[3,2,4]$.

The early years in the child's life cycle are considered as the fundamental starting point of inequality of opportunity at the physical cognitive and especially psychological level bearing in mind that these competencies develop early in life [5]. In other way, wellbrought up and well surrounded children have better chances to develop their knowledge [6], communication, social competencies, and grow healthy while having high self-esteem $[7,8]$. The early years of life have been described by some people as "a prolonged critical period and a real window opportunity for development that ends at three years stage" [9].

Underfeeding has a negative impact on economic and social development. Its effect can persist up to advanced stages in a human being's life and particularly children [9]. Throughout research, a number of studies show that biological and psycho-social risks affect individual development considerably by means of changes in structure and function of the brain which can lead to behavior changes, the latter will doubtlessly lead to a significant impact on the life of the individual and society [10].

To assess the extent of inequality in early childhood, we draw on the concepts and methodology developed in the recent literature on inequality of opportunity (De $[11,12,2,13])$. Using data from a surveys covering Tunisia, we examine the state of early childhood development in terms of early health services. We quantify the unequal opportunities children have to develop along health services using the dissimilarity index (De [11]) and decompose inequality into the contributions of different circumstances using the Shapley decomposition [13].

Inequality of opportunity in Tunisia is particularly high in access to health services between regions and in activities that support early cognitive development, which has important implications for inequality in children's subsequent labor force. Our analysis also illustrates the pathways through which circumstances shape children's early opportunities. Overall, wealth, mother's education, and geographic differences tend to contribute substantially to inequality of opportunity. This paper is the first paper that measures inequality of opportunities among children in Tunisia on selected health utilization, nutrition indicators using the Human Opportunity Index (HOI), which is a measure of inequality of opportunity in basic services for children.

Before presenting our findings in section 4, we organized our paper us follow: In section 2 , we present a conceptual framework for inequality of opportunity in early childhood development. Section 3 describes our empirical strategy and discusses the surveys and samples. Finally, section 5 provides implications of our findings and conclusions.

\section{A conceptual framework}

Based on the philosophical works elaborated by Rawls [14], Sen. [15], Dworkin [16, 17], Cohen [18]; Arenson [19] and Roemer [20,2], was the first to have introduced the concept of equality of chances in the economic literature. They distinguished between effort and circumstances in explaining divergences in wealth an opportunity in adulthood. The circumstances are defined as factors on which individuals have no control such as: ethnical origin sex, age, parental education...etc. This inequality of chances is widely considered unfair and deserving of attention from policy makers.

Our approach in this paper is based on Roemer's frameworks (1998) who present "model of advantage" to decompose outcomes into a controllable part (effort) and a non controllable condition(circumstances) that the States must intervene to reduce in order to guaranty social equity. This model can be presented as follow:

$$
y=f(C, E, u)
$$

Where $y$, designates the considered outcome, $C$ and $E$ are respectively vectors of circumstances and effort variables and $u$ represents the random factors. As noted above, Roemer's theory (1998) presumes explicitly that circumstances must be economically exogenous i.e. the person can't control over them. Conversely, efforts may be endogenous and may therefore depend on circumstances as shown in the following equation: 


$$
y=f[C, E(c, v), u]
$$

According to Roemer, realizing an equality of opportunities requires that $\mathrm{F}(\mathrm{y} / \mathrm{C})=\mathrm{F}(\mathrm{y})$ which means simultaneously that no circumstance variable should have a direct causal impact on variable y $(\partial f(C, E, u) / \partial C=0)$, each effort variable should be distributed independently from all circumstances $G(y / C)=G(y)$. Furthermore, Random factors are independent from circumstances $\mathrm{H}(\mathrm{y} / \mathrm{C})=\mathrm{H}(\mathrm{y})$ where all three functions $\mathrm{F}, \mathrm{G}$ and $\mathrm{H}$ denote cumulative distributions. Subsequently, an inequality of opportunity occurred when $F(y / C) \neq F(y)$ and the extent of this inequality could be measured by the difference between the two members of the previous inequality. This last inequality has been defined as Roemer's strong definition of inequality of opportunity in a several recent papers, including Bourguignon et al., [3]; Ferreira and Gignoux [21].

So, earlier literature seeking to separate the effect of efforts from circumstances (out of control) has led to the emergence of the concept "Human opportunity index". It corresponds to a synthetic measure of opportunities inequality, proposed for the first time by the social welfare function of Sen [22] and developed by the Word Bank on 2006. This index is firstly applied to measure inequality of opportunity in access to basic services in Latin America and Caraib by De Barro and al., [23]. Since then, this measure has been widely used in the literature of inequalities but the results are different may be because of the used measures of inequalities. This tool has the advantage of giving an idea on the level of accessibility to any service by a given population and gives the level of discrepancies in sample in terms of access to this service. In other words, it helps respond to these preoccupations: (i) How many opportunities are available to a childhood in any region of a given country (the coverage rate by a basic service). (ii) How equitably those opportunities are distributed (whether the dissimilarity in individual access to the same service is due to exogenous circumstances and inequality of chances). We are largely based on the idea presented in this section in developing our methodology. We constructed a conceptual and empirical frameworks permitting us explain inequality in access to basic services by Tunisian children.

\section{Data and methodology}

\section{Data choice and descriptions}

We use data from the Multiple Indicator Cluster Surveys (MICS4), this survey was executed in 2011-2012 by the Ministry of Development and Cooperation with the National Institute of Statistics of Tunisia (INS), financial and technical support was provided by the United Nations Children's Emergency Fund (UNICEF), the United Nations Population Fund (UNFPA) and the Swiss Cooperation Office in Tunisia. It is the only recent database available until our day, which contains rich information on the situation of women and children in this country.

We use also data concerning place of residence, socio-economic and demographic indicators for three governorates of the center (Kasserine, Kairouan and Zidi-Bouzid) and for six regions of the country (District Tunis, North East, North West, Center East, South East and South West). Otherwise, we use 8 variables of circumstances: residence, age of household's head, family wealth index, sex of household head, gender, number of children per household, level of education of household head and household size.

Firstly, to study nutrition situation of Tunisian children we are based on a sample of 9600 selected households where 2938 children under 5 years were identified through the household question sheet. This question sheet was filled for 2768 of these children, which corresponds to a $94.2 \%$ answer rate among households with children under 5 years interviewed [24]. Descriptive statistics containing demographic information about of this sample are presented in the Table 10 Appendix. Then, to analyze the development of babies' health in Tunisia, we use crucial index measuring opportunity access to basic services using data provided by the INS (2011-2012). The database covers 9867 women interviewed, of whom 4204 gave birth and 1059 gave birth during the last 2 years before the interview. The first sample of women, that have had children since 1982 until 2012, allows us to see the disparities in terms of access to basic health services for children. The last database which contains 1059 women who gave birth in the last years preceding the questionnaire is important in the sense that it allows us to follow the evolution of inequalities of chances in relation to previous years.

For the choice of our variables, we are based on important indicators and outcomes identified in previous literature, and as constrained by the data availability, we considered nutritional and health care utilization variables as our proxy for health services access.

The nutritional status of children is a reflection of their overall health. When children have access to adequate food, are not exposed to repeated morbid episodes and are healthy, they reach their growth potential and are considered well fed. Malnutrition is responsible for more than half of all child deaths worldwide. Undernourished children are more likely to die from common childhood illnesses and those who survive have recurrent diseases and stunted growth. One of the main goals of World Health Organization is to reduce the proportion of people who suffer from 
hunger. A reduction in the prevalence of malnutrition will also help to reduce infant mortality. In a wellnourished population, there is a reference distribution of the size and weight of children under 5 years of age. Under-nutrition in a population can be measured by comparing children to the reference population. The reference population used in this work is based on the WHO growth standards. Each of the three indicators of nutritional status can be expressed in units of standard deviations (reduced deviation) from the median of the reference population (Tables 13 and 14 in the Appendix).

Weight-for-age is a measure of both acute and chronic malnutrition. Children whose weight-for-age is more than two standard deviations below the median of the reference population are considered to be low or moderate underweight, while those whose weight-for-age is more than three standard deviations below the median are considered to be severely underweight(Table 13).

The length-for-age is a measure of linear growth. Children whose height-for-age is more than two standard deviations below the median of the reference population are considered to be too small for their age and are classified as having moderate or severe growth retardation. Those whose height-for-age is more than three standard deviations below the median are classified as having severe growth retardation. Stunting is a reflection of chronic malnutrition resulting from lack of adequate nutrition over a long period of time and from recurrent or chronic diseases (Table 13).

Finally, children whose weight-for-height is more than two standard deviations below the median of the reference population are classified as moderately or severely emaciated, while those with more than three standard deviations below the median are considered severely emaciated. Emaciation is generally the result of a recent nutritional deficiency. The indicator may have significant seasonal variations associated with changes in food availability or disease prevalence (Table 14).

Table 1 shows the percentages of children in each of these categories, based on the anthropometric measurements taken during the fieldwork. Based on the new WHO growth standards, ${ }^{1} 2.57 \%$ of children under 5 years old in Tunisia are underweight (moderate or severe). Approximately one of ten children (10.33\%) suffers from moderate or severe stunting and $2.2 \%$ are moderately or severely emaciated.

There are also variations in anthropometric indicators according to socio-demographic characteristics; boys appear to be slightly more likely than girls to accuse underweight, stunting, and emaciation. Disparities by environment are characterized by a higher prevalence of moderate or severe growth retardation in rural areas $(\approx 14 \%)$ than in urban areas $(8 \%)$. In terms of geographical variations, we can see a higher prevalence of underweight in the South West, Sidi Bouzid, Kairouan and North West (4\%), while the prevalence of moderate or severe growth problem is touched in Kasserine (13.83\%), in south-west, sidi bouzid, kairouan and north-west (more than 13\%).

Children whose mothers/guardians with secondary or superior education are the least likely to be underweight and stunted compared to the children of mothers who have never attended school. As for the disparities according to the level of economic well-being, the prevalence of underweight and stunting are higher among the poorest.

Similarly, the prenatal period offers important opportunities to provide services that may be essential to the health of pregnant women and their infants [25]. A better understanding of the growth and development of the fetus and its relationship to maternal health has led to increased attention to prenatal care, which has been widely demonstrated to have an impact on improving maternal and neonatal health. For example, if the prenatal period is used to inform women and families about warning signs, symptoms and risks related to labor and delivery, it can guide women to give birth in the best possible way with the assistance of qualified care personnel. The prenatal period also provides an opportunity to provide information on birth spacing, recognized as an important factor in improving infant survival. Tetanus vaccination during pregnancy can save both mother and infant life. Preventing and treating malaria in pregnant women, managing anemia during pregnancy and treating STIs (sexually transmitted infections) can greatly improve the chances of survival of the fetus and the health of the mother. Adverse outcomes such as low birth weight can be prevented through a combination of interventions to improve the nutritional status of women and prevent infections (eg, malaria and STIs) during pregnancy. More recently, the potential of the prenatal period as an entry point for the prevention of HIV (Human Immunodeficiency Virus) and care, especially for the prevention of mother-to-child transmission of HIV, has lead to renewed interest in the access and use of prenatal care services.

World Health Organization recommends a minimum of four antenatal visits based on an analysis of the effectiveness of different antenatal care models. WHO guidelines are specific to the content of prenatal consultations, including: measurement of blood pressure; Urine analysis for bacteriuria and proteinuria; Blood testing to detect syphilis and severe anemia; and weight/length measurement (optional). 
Table 1 Basic characteristics of children under 5 years according to selected characteristics (Nutrition)

\begin{tabular}{|c|c|c|c|c|c|c|c|c|}
\hline \multirow[t]{2}{*}{ Tunisia (2011-2012) } & & & \multicolumn{2}{|c|}{ Nutrition: Weight for Age } & \multicolumn{2}{|c|}{ Nutrition: Height for Age } & \multicolumn{2}{|c|}{ Nutrition: Weight for height } \\
\hline & & & Underweight & $\begin{array}{l}\text { No ponderal } \\
\text { insufficiency }\end{array}$ & $\begin{array}{l}\text { Growth } \\
\text { delay }\end{array}$ & $\begin{array}{l}\text { No growth } \\
\text { delay }\end{array}$ & Emarciation & No emarciation \\
\hline & Total & $\begin{array}{l}2768 \\
100.00\end{array}$ & $\begin{array}{l}71 \\
2.57\end{array}$ & $\begin{array}{l}2697 \\
97.43\end{array}$ & $\begin{array}{l}286 \\
10.33\end{array}$ & $\begin{array}{l}2482 \\
89.67\end{array}$ & $\begin{array}{l}61 \\
2.20\end{array}$ & $\begin{array}{l}2707 \\
97.80\end{array}$ \\
\hline \multirow[t]{2}{*}{ Gender } & Male & $\begin{array}{l}1482 \\
53.54\end{array}$ & $\begin{array}{l}48 \\
3.24\end{array}$ & $\begin{array}{l}1434 \\
96.76\end{array}$ & $\begin{array}{l}163 \\
11.00\end{array}$ & $\begin{array}{l}1319 \\
89.00\end{array}$ & $\begin{array}{l}40 \\
2.70\end{array}$ & $\begin{array}{l}1442 \\
97.30\end{array}$ \\
\hline & Female & $\begin{array}{l}1286 \\
46.46\end{array}$ & $\begin{array}{l}23 \\
1.79\end{array}$ & $\begin{array}{l}1263 \\
98.21\end{array}$ & $\begin{array}{l}123 \\
9.56\end{array}$ & $\begin{array}{l}1163 \\
90.44\end{array}$ & $\begin{array}{l}21 \\
1.63\end{array}$ & $\begin{array}{l}1265 \\
98.37\end{array}$ \\
\hline \multirow[t]{2}{*}{ Residence } & Urbain & $\begin{array}{l}1607 \\
58.06\end{array}$ & $\begin{array}{l}41 \\
2.55\end{array}$ & $\begin{array}{l}1566 \\
97.45\end{array}$ & $\begin{array}{l}126 \\
7.84\end{array}$ & $\begin{array}{l}1481 \\
92.16\end{array}$ & $\begin{array}{l}38 \\
2.36\end{array}$ & $\begin{array}{l}1569 \\
97.64\end{array}$ \\
\hline & Rural & $\begin{array}{l}1161 \\
41.94\end{array}$ & $\begin{array}{l}30 \\
2.58\end{array}$ & $\begin{array}{l}1131 \\
97.42\end{array}$ & $\begin{array}{l}160 \\
13.78\end{array}$ & $\begin{array}{l}1001 \\
86.22\end{array}$ & $\begin{array}{l}23 \\
1.98\end{array}$ & $\begin{array}{l}1138 \\
98.02\end{array}$ \\
\hline \multirow[t]{9}{*}{ Region } & District Tunis & $\begin{array}{l}356 \\
12.86\end{array}$ & $\begin{array}{l}5 \\
1.40\end{array}$ & $\begin{array}{l}351 \\
98.60\end{array}$ & $\begin{array}{l}24 \\
6.74\end{array}$ & $\begin{array}{l}332 \\
93.26\end{array}$ & $\begin{array}{l}10 \\
2.81\end{array}$ & $\begin{array}{l}346 \\
97.19\end{array}$ \\
\hline & North East & $\begin{array}{l}379 \\
13.69\end{array}$ & $\begin{array}{l}8 \\
2.11\end{array}$ & $\begin{array}{l}371 \\
97.89\end{array}$ & $\begin{array}{l}37 \\
9.76\end{array}$ & $\begin{array}{l}342 \\
90.24\end{array}$ & $\begin{array}{l}6 \\
1.58\end{array}$ & $\begin{array}{l}373 \\
98.42\end{array}$ \\
\hline & North west & $\begin{array}{l}291 \\
10.51\end{array}$ & $\begin{array}{l}10 \\
3.44\end{array}$ & $\begin{array}{l}281 \\
96.56\end{array}$ & $\begin{array}{l}38 \\
13.06\end{array}$ & $\begin{array}{l}253 \\
86.94\end{array}$ & $\begin{array}{l}4 \\
1.37\end{array}$ & $\begin{array}{l}287 \\
98.63\end{array}$ \\
\hline & Centre East & $\begin{array}{l}308 \\
11.13\end{array}$ & $\begin{array}{l}5 \\
1.62\end{array}$ & $\begin{array}{l}303 \\
98.38\end{array}$ & $\begin{array}{l}18 \\
5.84\end{array}$ & $\begin{array}{l}290 \\
94.16\end{array}$ & $\begin{array}{l}8 \\
2.60\end{array}$ & $\begin{array}{l}300 \\
97.40\end{array}$ \\
\hline & Kasserine & $\begin{array}{l}282 \\
10.19\end{array}$ & $\begin{array}{l}5 \\
1.77\end{array}$ & $\begin{array}{l}277 \\
98.23\end{array}$ & $\begin{array}{l}39 \\
13.83\end{array}$ & $\begin{array}{l}243 \\
86.17\end{array}$ & $\begin{array}{l}7 \\
.48\end{array}$ & $\begin{array}{l}275 \\
97.52\end{array}$ \\
\hline & Kairouan & $\begin{array}{l}305 \\
11.02\end{array}$ & $\begin{array}{l}11 \\
3.61\end{array}$ & $\begin{array}{l}294 \\
96.39\end{array}$ & $\begin{array}{l}40 \\
13.11\end{array}$ & $\begin{array}{l}265 \\
86.89\end{array}$ & $\begin{array}{l}5 \\
1.64\end{array}$ & $\begin{array}{l}300 \\
98.36\end{array}$ \\
\hline & Sidi Bouzid & $\begin{array}{l}250 \\
9.03\end{array}$ & $\begin{array}{l}10 \\
4.00\end{array}$ & $\begin{array}{l}240 \\
96.00\end{array}$ & $\begin{array}{l}33 \\
13.20\end{array}$ & $\begin{array}{l}217 \\
86.80\end{array}$ & $\begin{array}{l}6 \\
2.40\end{array}$ & $\begin{array}{l}244 \\
97.60\end{array}$ \\
\hline & South East & $\begin{array}{l}347 \\
12.54\end{array}$ & $\begin{array}{l}6 \\
1.73\end{array}$ & $\begin{array}{l}341 \\
98.27\end{array}$ & $\begin{array}{l}24 \\
6.92\end{array}$ & $\begin{array}{l}323 \\
93.08\end{array}$ & $\begin{array}{l}9 \\
2.59\end{array}$ & $\begin{array}{l}338 \\
97.41\end{array}$ \\
\hline & South Ouest & $\begin{array}{l}250 \\
9.03\end{array}$ & $\begin{array}{l}11 \\
4.40\end{array}$ & $\begin{array}{l}239 \\
95.60\end{array}$ & $\begin{array}{l}33 \\
13.20\end{array}$ & $\begin{array}{l}217 \\
86.80\end{array}$ & $\begin{array}{l}6 \\
2.40\end{array}$ & $\begin{array}{l}244 \\
97.60\end{array}$ \\
\hline \multirow[t]{4}{*}{ Mather's education } & Nothingness & $\begin{array}{l}466 \\
16.84\end{array}$ & $\begin{array}{l}21 \\
4.51\end{array}$ & $\begin{array}{l}445 \\
95.49\end{array}$ & $\begin{array}{l}79 \\
16.95\end{array}$ & $\begin{array}{l}387 \\
83.05\end{array}$ & $\begin{array}{l}9 \\
1.93\end{array}$ & $\begin{array}{l}457 \\
98.07\end{array}$ \\
\hline & $\begin{array}{l}\text { Primary } \\
\text { and similar }\end{array}$ & $\begin{array}{l}917 \\
33.13\end{array}$ & $\begin{array}{l}16 \\
1.74\end{array}$ & $\begin{array}{l}901 \\
98.26\end{array}$ & $\begin{array}{l}101 \\
11.01\end{array}$ & $\begin{array}{l}816 \\
88.99\end{array}$ & $\begin{array}{l}17 \\
1.85\end{array}$ & $\begin{array}{l}900 \\
98.15\end{array}$ \\
\hline & $\begin{array}{l}\text { Secondary } \\
\text { and similar }\end{array}$ & $\begin{array}{l}951 \\
34.36\end{array}$ & $\begin{array}{l}23 \\
2.42\end{array}$ & $\begin{array}{l}928 \\
97.58\end{array}$ & $\begin{array}{l}79 \\
8.31\end{array}$ & $\begin{array}{l}872 \\
91.69\end{array}$ & $\begin{array}{l}21 \\
2.21\end{array}$ & $\begin{array}{l}930 \\
97.79\end{array}$ \\
\hline & Superior & $\begin{array}{l}434 \\
15.68\end{array}$ & $\begin{array}{l}11 \\
2.53\end{array}$ & $\begin{array}{l}423 \\
97.47\end{array}$ & $\begin{array}{l}27 \\
6.22\end{array}$ & $\begin{array}{l}407 \\
93.78\end{array}$ & $\begin{array}{l}14 \\
3.23\end{array}$ & $\begin{array}{l}420 \\
96.77\end{array}$ \\
\hline \multirow[t]{5}{*}{$\begin{array}{l}\text { Annual family incomes } \\
\text { (Economic quintile) }\end{array}$} & The poorest & $\begin{array}{l}737 \\
26.63\end{array}$ & $\begin{array}{l}30 \\
4.07\end{array}$ & $\begin{array}{l}707 \\
95.93\end{array}$ & $\begin{array}{l}118 \\
16.01\end{array}$ & $\begin{array}{l}619 \\
83.99\end{array}$ & $\begin{array}{l}13 \\
1.76\end{array}$ & $\begin{array}{l}724 \\
98.24\end{array}$ \\
\hline & Second & $\begin{array}{l}606 \\
21.89\end{array}$ & $\begin{array}{l}11 \\
1.82\end{array}$ & $\begin{array}{l}595 \\
98.18\end{array}$ & $\begin{array}{l}72 \\
11.88\end{array}$ & $\begin{array}{l}534 \\
88.12\end{array}$ & $\begin{array}{l}14 \\
2.31\end{array}$ & $\begin{array}{l}592 \\
97.69\end{array}$ \\
\hline & Medium & $\begin{array}{l}479 \\
17.30\end{array}$ & $\begin{array}{l}11 \\
2.30\end{array}$ & $\begin{array}{l}468 \\
97.70\end{array}$ & $\begin{array}{l}29 \\
6.05\end{array}$ & $\begin{array}{l}450 \\
93.95\end{array}$ & $\begin{array}{l}9 \\
1.88\end{array}$ & $\begin{array}{l}470 \\
98.12\end{array}$ \\
\hline & Fourth & $\begin{array}{l}565 \\
20.41\end{array}$ & $\begin{array}{l}11 \\
1.95\end{array}$ & $\begin{array}{l}554 \\
98.05\end{array}$ & $\begin{array}{l}46 \\
8.14\end{array}$ & $\begin{array}{l}519 \\
91.86\end{array}$ & $\begin{array}{l}13 \\
2.30\end{array}$ & $\begin{array}{l}552 \\
97.70\end{array}$ \\
\hline & The richest & $\begin{array}{l}381 \\
13.76\end{array}$ & $\begin{array}{l}8 \\
2.10\end{array}$ & $\begin{array}{l}373 \\
97.90\end{array}$ & $\begin{array}{l}21 \\
5.51\end{array}$ & $\begin{array}{l}360 \\
94.49\end{array}$ & $\begin{array}{l}12 \\
3.15\end{array}$ & $\begin{array}{l}369 \\
96.85\end{array}$ \\
\hline
\end{tabular}

The second value in the table corresponds to the percentage contribution in the corresponding sample

In this framework, we present the level of health care coverage in Table 2 and the type of staff providing prenatal care to women aged 15-49 who gave birth in the two years preceding the survey in Table 15 Appendix. This table shows that access to antenatal care is relatively high in the country as a whole 


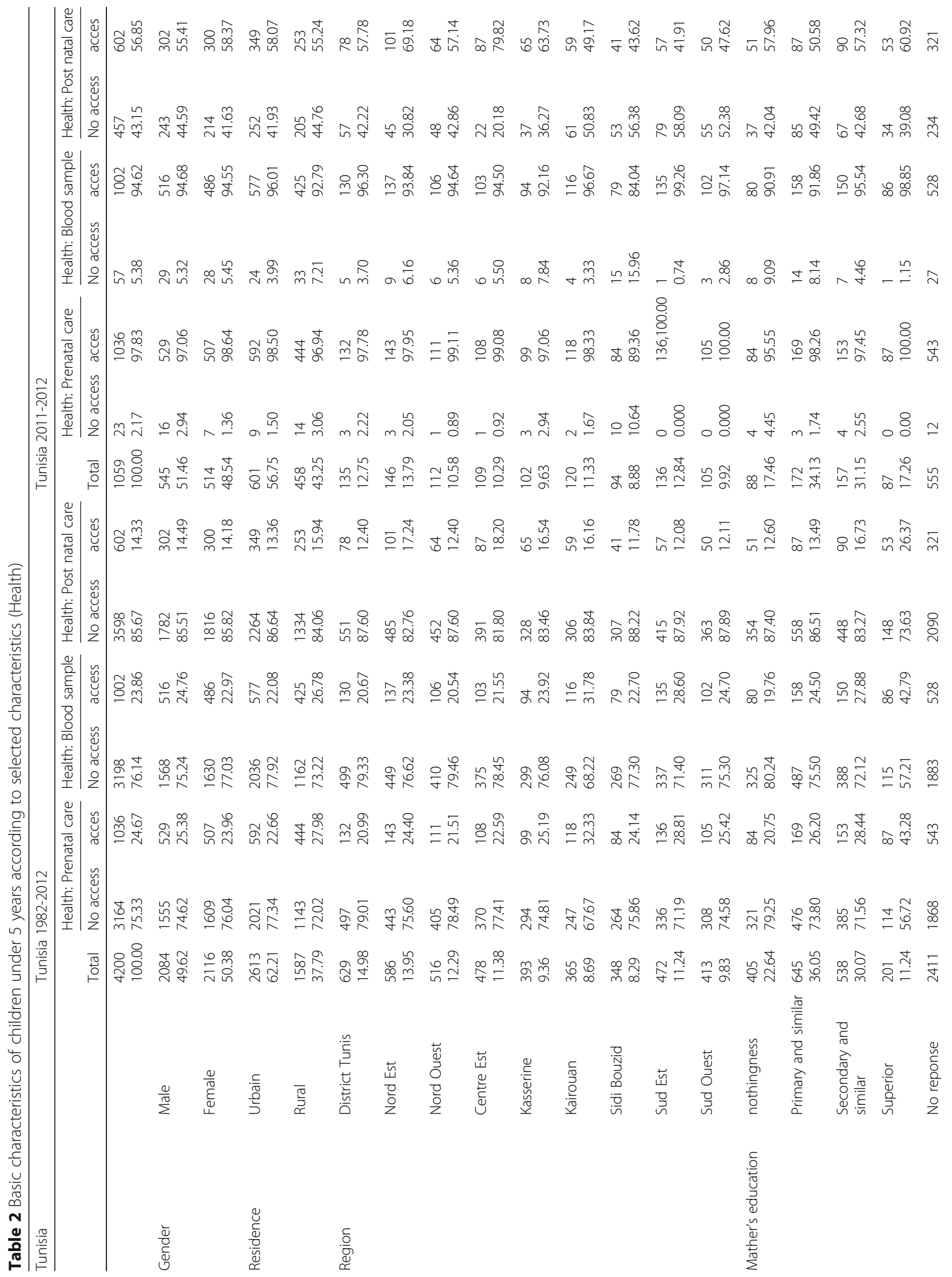




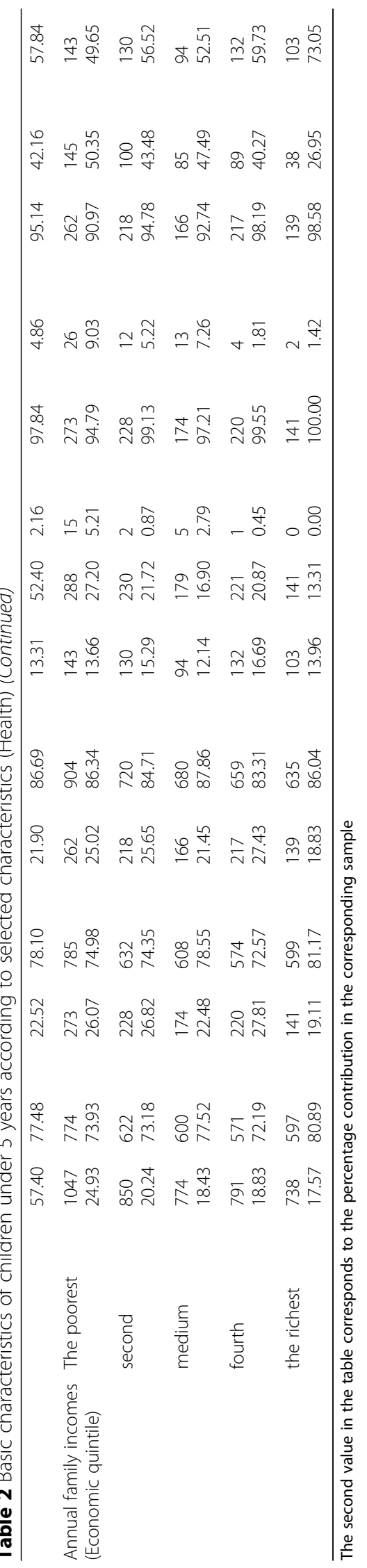


with $97.83 \%$ of women receiving prenatal care at least one time during pregnancy $(79.03 \%$ per doctor and $44.47 \%$ per auxiliary midwife). The highest levels of prenatal care are observed in the South East and South West regions (100\%); while the lowest level is in the Sidi Bouzid region (89.36\%). There are few differences among children following residence $(98.50 \%$ in urban areas versus $96.94 \%$ in rural areas). This coverage is around $97.06 \%$ for boys and $98.64 \%$ for girls. It increases with women's educational attainment (from 95.55 to 100\%) and the level of economic well-being of households. Of the women surveyed and concerned with antenatal care, $79.03 \%$ were examined by a physician during pregnancy; this proportion is higher in urban areas $(82.69 \%)$ than in rural areas $(74.23 \%)$. It is higher among women residing in the Central East region (93.57\%), women with university education $(93.10 \%)$, and women in the richest household category $(97.87 \%)$. The lowest proportions were found among women who had never attended school (67.04\%) and those in the governorate of Kairouan (67.50\%) and the South West region (68.57\%). This level of coverage has been low in previous decades and is approaching an average of $25 \%$ throughout the study period. The distribution is similar for blood samples with a slight decrease in the level of coverage, which drops to $94.62 \%$ in 2012 and does not exceed 24\% (23.86\%) over the period from 1982 until the date of the survey always with a small advantage of the southern regions.

In Tunisia, two postnatal consultations are recommended: on the eighth and fortieth day after childbirth [26].. However, no question on these two visits is included in the questionnaire. This survey revealed that $85.67 \%$ of newborns had no postnatal consultation during the first 6 days after birth between 1982 and 2012 , while $43.15 \%$ born in the 2 years prior to the survey received no postnatal care (Table 2). This percentage is the highest in Sidi Bouzid ( $88.22 \%$ over the entire period and $56.38 \%$ in 2012) and it is the lowest in the Center East (81.80 and 20.18\%). There are few differences on average between urban areas $(86.64 \%)$ and rural areas $(84.06 \%)$. This percentage decreases with the level of economic well-being and with the level of schooling of the mother.

\section{Methodology}

As indicated previously, we aim to study inequality in early childhood access to basic services. Otherwise, our variables of interest are binary meaning two possibilities either access or not. So, we follow De Barros [23], Son [27] to define a dichotomous variable $z i$ which takes a value of 1 if the $i$ th person of specific group has access to basic opportunity and takes a value of 0 if he lacks access to the considered opportunity. It can be readily proved that $(z i)=p i=$ $(z i)$, where $p i$ is the average accomplishment related to the dichotomous outcome (zi) with respect to a specific group of sample. $p i$ could be defined otherwise as the probability that the $i$ th person has access to a given opportunity. It depends on a vector of exogenous variables indicating the socioeconomic circumstances (such as gender, age, area of residence...) of each group, the total characteristic being $k$. There can be as many probability gaps between individuals/ groups as there are possible combinations of groupidentifying circumstances (income groups, householdsize groups, gender groups...).

Given a set of $k$ circumstance variables $x i 1, x i 2 \ldots x i k$, we estimate the probability $p i$ for each child (In this study we focus particularly on children as we assume that many of the differences in opportunities are generated during childhood and carried out the whole life) by means of a logit model. Accordingly, we have the following expression of:

$$
p_{i}=\frac{e^{\left(\beta_{0}+\sum_{j=1}^{k} \beta_{j} x_{i j}\right)}}{1+e^{\left(\beta_{0}+\sum_{j=1}^{k} \beta_{j} x_{i j}\right)}}
$$

Secondly, we compute the overall coverage rate $\bar{p}$ which is the proportion of the population with access to a given opportunity using the following formula:

$$
\overline{\mathrm{p}}=\sum_{\mathrm{i}=1}^{\mathrm{n}} \mathrm{w}_{\mathrm{i}} \widehat{\mathrm{p}}_{\mathrm{i}}
$$

Where $\mathrm{w}_{\mathrm{i}}=\frac{1}{\mathrm{n}}$ and $\mathrm{n}$ is the size of sample considered. Then, the Dissimilarity Index $\mathrm{D}$ can be computed as follows:

$$
\widehat{\mathrm{D}}=\frac{1}{2 \overline{\mathrm{p}}} \sum_{\mathrm{i}=1}^{\mathrm{k}} \mathrm{w}_{\mathrm{i}}\left|\widehat{\mathrm{p}}_{\mathrm{i}}-\overline{\mathrm{p}}\right|
$$

After calculating the penalty which is equal to $\mathrm{P}=\mathrm{C} \times \mathrm{D}$, we get the final formula of the $\mathrm{HOI}$ for each service or outcome:

$$
\mathrm{HOI}=\overline{\mathrm{p}}(1-\mathrm{D})
$$

Human opportunity index specification provides an overview in the differences between regions in terms of percentage coverage by any service in addition to dissimilarity level but it is silent about origin of inequality. To overtake this limit, we refer to Shapley Decomposition methodology that consists in identifying how each circumstance "contributes" to 
Inequality in access to basic services [28, 29, 13]. ${ }^{2}$ This approach extends the idea of the Shapley value of cooperative games into applications for decomposing inequality. The decomposition consists of calculating the marginal contributions of each circumstance as they are removed in sequence. Following Barros et al. [11], and [13], we can measure inequality of opportunities by the penalty $(\mathrm{P})$ or by the dissimilarity index (D), as defined in expressions (4) and (5) above. The value of these two measures-where $P$ is just a scalar transformation of D-is dependent on the set of circumstances considered. Moreover, they have the important property that adding more circumstances always increases the value of $\mathrm{P}$ and $\mathrm{D}$. If we have two sets of circumstances $\mathrm{A}$ and $\mathrm{B}$, and set $\mathrm{A}$ and $\mathrm{B}$ do not overlap, then $\mathrm{HOI}(\mathrm{A}, \mathrm{B}) \leq \mathrm{HOI}(\mathrm{A})$; and alternatively, $\mathrm{D}(\mathrm{A}, \mathrm{B}) \geq \mathrm{D}(\mathrm{A})$. The impact of adding a circumstance $\mathrm{A}$ is given by:

$$
\begin{aligned}
& {[\mathrm{D}(\mathrm{s}\{\mathrm{A}\}-\mathrm{D}(\mathrm{S})]} \\
& \mathrm{D}_{\mathrm{A}}=\sum_{\mathrm{S} \subseteq \mathrm{N}\{\mathrm{A}\}} \frac{|\mathrm{s}| !(\mathrm{n}-|\mathrm{S}|-1) !}{\mathrm{n} !}[\mathrm{D}(\mathrm{S} \cup\{\mathrm{A}\})-\mathrm{D}(\mathrm{S})]
\end{aligned}
$$

Where $N$ is the set of all circumstances, which includes $n$ circumstances in total; $S$ is a subset of $N$ that does not contain the particular circumstance $A . D(S)$ is the dissimilarity index estimated with the set of circumstances $S . \mathrm{D}(\mathrm{S} \cup\{\mathrm{A}\})$ is the dissimilarity index calculated with set of circumstances $S$ and the circumstance $A$. The contribution of circumstance A to the dissimilarity index can be defined as:

$$
\mathrm{M}_{\mathrm{A}}=\frac{\mathrm{D}_{\mathrm{A}}}{\mathrm{D}(\mathrm{N})} \text { where } \sum_{\mathrm{i} \in \mathrm{N}} \mathrm{M}_{\mathrm{i}}=1
$$

We measure variations in HOI in Tunisia in the time period surveyed based on 2 main indicator categories: (i) Malnutrition Intake, and (ii) Healthcare utilization before, during pregnancy to healthcare services in early year using data from the 2011 and 2012 (MICS4) samples.

\section{Results and discussions}

We present our results and interpretations in terms of coverage beginning by the nutritional status of children in Tunisia during the period of the survey elaboration then by access to health care services before, after, and during pregnancy.

\section{Access to nutritional services by Tunisian childhood Results}

Given the importance of nutrition and its influence on the health status and early childhood mortality rate, it should be noted that in a well-nourished population there is a standard distribution of the height and weight of children less than five years aged. Under-nutrition in a population can be measured by comparing children to the reference population. ${ }^{3}$ Stunting indicates accumulated malnutrition, damages psycho-social development [30] and engenders poorer school performance leading to lower productivity and so wages later in life, according to classical theory [31]. Indeed, it results that there are variations of the anthropometric indicators according to the socio-demographic characteristics.

Table 3 shows that for the first model, when we consider weight for age ratio as the dependent variable, household's size increase significantly at the 5\% threshold underweight problem. ${ }^{4}$ However, head's household age, number of children (2-14) per household and head's household education level decreases significantly the probability of children to suffer from problem of underweight. Concerning determinants of children's stunting, it seems that household's education level, high family income, male nature and age of head's household significantly reduces the likelihood to have problem of growth during the first five years of birth (second column). Similarly, a child who belongs to a large family may significantly have problems of emaciation, whereas if he or she lives with more than one child (2-14) he or she becomes more protected against this type of problem (last column).

Table 4 presents results of HOI regressions which give an idea about nutritional status of children in each region in the Tunisian areas. If we interpret our results in terms of coverage, we can see that it is almost satisfactory for the 3 indicators of nutrition such us weight for age, height for age and weight for height are respectively $97.43 \%, 89.66 \%$, and $97.79 \%$.

The first indicator that measures both acute and chronic malnutrition (weight-for-age) is $97.43 \%$ meaning that $97.43 \%$ of children among all population of reference have the opportunity to be well nourished. The corresponding D-index (which measures inequality) implies that $0.6 \%$ of opportunities must be redistributed fairly to ensure equality of opportunity in terms of protection against malnutrition. Thus, associated HOI which is coverage penalized for inequality $(C *(1-D)]$ is estimated to be $96.8 \%$.

Concerning height for age which measures linear growth, we can see that $89.66 \%$ of Tunisian's children have the opportunity to grow normally with a slow Dindex of $2.18 \%$ and a HOI of $87.71 \%$. Finally, the latest 
Table 3 Results of logit model (Nutrition)

\begin{tabular}{|c|c|c|c|c|c|c|}
\hline \multirow{2}{*}{$\begin{array}{l}\text { Endogenous variables } \\
\text { Exogenous Variables }\end{array}$} & \multicolumn{2}{|c|}{ Nutrition: Weight for Age } & \multicolumn{2}{|c|}{ Nutrition: Height for Age } & \multicolumn{2}{|c|}{ Nutrition: Weight for height } \\
\hline & Coef & $P$-Value & Coef & $P$-Value & Coef & $P$-Value \\
\hline Gender & -.041 & 0.865 & -.033 & 0.794 & -.315 & 0.233 \\
\hline Residence & -.488 & 0.103 & .191 & 0.208 & -.166 & 0.610 \\
\hline Head's household Education & .865 & 0.022 & .565 & 0.004 & .418 & 0.368 \\
\hline Household income & .355 & 0.228 & .605 & 0.000 & -.110 & 0.727 \\
\hline Head's household gender & -1.07 & 0.294 & .747 & 0.003 & -1.00 & 0.331 \\
\hline Household size & -.417 & 0.000 & -.064 & 0.256 & -.227 & 0.023 \\
\hline Number of children (2-14) & .288 & 0.011 & .014 & 0.828 & .415 & 0.002 \\
\hline Head's household age & .063 & 0.000 & .019 & 0.009 & .024 & 0.131 \\
\hline Constant & 3.13 & 0.010 & .128 & 0.763 & 4.16 & 0.001 \\
\hline Obs & 2768 & & 2768 & & 2768 & \\
\hline Prob > chi2 & 0.0000 & & 0.0000 & & 0.0543 & \\
\hline
\end{tabular}

nutritional weight-for-height indicator (which measures emaciation) shows a coverage rate of $97.79 \%$. That is, 97.79\% of children in Tunisia have the opportunity to be sufficiently and efficiently nourished.

Despite the high level of anthropometric indicators throughout the country, there is a disparity between regions. Indeed, weight-for-age (which detects both acute and chronic malnutrition) is found to be low in inland areas compared to littoral regions. For example, in Sidi Bouzid, in the South West, in Kairoaun and in the North West, 95.74\%; 95.03\%; 96.23\% and 95.55\% are respectively found, while in district Tunis and in the Center East we find $98.10 \%$ and 98.26\%, respectively.

Similarly, height for age which is a linear growth indicator and weight-for-age (the indicator of emaciation) are also low in western and inland regions (such as

Table 4 Rate of anthropometric indicators coverage by region

\begin{tabular}{llll}
\hline & $\begin{array}{l}\text { Weight for age } \\
\text { (Malnutrition \%) }\end{array}$ & $\begin{array}{l}\text { Height for age } \\
\text { (stunting \%) }\end{array}$ & $\begin{array}{l}\text { Weight for height } \\
\text { (Emaciation) }\end{array}$ \\
\hline Great Tunis & $98.10(0.63)$ & $93.25(2.12)$ & $96.21(0.69)$ \\
North East & $97.80(0.82)$ & $90.23(2.7)$ & $98.24(0.40)$ \\
North West & $95.55(2.13)$ & $86.94(4.94)$ & $98.15(0.47)$ \\
Center east & $98.26(0.79)$ & $94.15(0.90)$ & $97.22(1.03)$ \\
Kasserine & $98.15(1.06)$ & $86.17(2.52)$ & $97.41(0.96)$ \\
Kairouan & $96.23(2.30)$ & $86.88(4.95)$ & $98.28(1.16)$ \\
Sidi Bouzid & $95.74(1.5)$ & $86.80(3.47)$ & $97.02(1.71)$ \\
South East & $98.07(0.42)$ & $93.08(2.16)$ & $97.32(1.21)$ \\
South West & $95.02(1.63)$ & $86.25(2.83)$ & $97.28(1.07)$ \\
Tunisia & $97.43(0.6)$ & $89.66(2.18)$ & $97.79(0.42)$ \\
\hline
\end{tabular}

Numbers in parenthesis are corresponding D-index values kairouan and sidi bouzid and middle west) than in regions in the east of the country (littoral) as shown in the Table 4 below, showing the regional coverage for 3 nutritional indicators.

Otherwise, Table 4 shows that anthropometric indicators vary according to socio-demographic and regional criteria in Tunisia. Despite good nutritional indices at the national level, it seems that there are many regional imbalances and disparities in access to these primary services. In this sense, it appears that children in the western, southwestern regions (with low coverage) are more susceptible to suffer from stunting, problems of emaciation and underweight (Malnutrition). For example, South west region presents the lowest rate of coverage against stunting problem (only $86.25 \%$ of children are protected) while the center east present the highest level of coverage (with more than 94.00\%). Concerning dissimilarity at the same region, we note that children of the center east are more mo meaning that they have comparable chances to be covered against stunting (less than 1\%). For children living in North West and Kairouan inequality between childhoods in terms of protection against nutritional problems is again remarkable (Dindex $=4.95 \%$ for stunting problem in Kairouan). To give sense to our analysis and searching to quantify the contribution of circumstances variables in explaining inequality we are based on the Shapley decomposition and results are presented below:

Table 5 illustrates a Shapley decomposition result which consists at identifying sources of dissimilarity in terms of anthropometric services. From this table, it appears that the "household size" best explains both acute and chronic malnutrition of children followed by 'head's household age'. This result confirms our conclusions 
Table 5 Shapely decomposition of regional nutritional disparities by circumstances

\begin{tabular}{|c|c|c|c|c|c|c|c|c|c|}
\hline & Gender & Residence & $\begin{array}{l}\text { Head's household } \\
\text { education }\end{array}$ & $\begin{array}{l}\text { Wealth } \\
\text { index }\end{array}$ & $\begin{array}{l}\text { Household } \\
\text { gender }\end{array}$ & $\begin{array}{l}\text { Household } \\
\text { size }\end{array}$ & $\begin{array}{l}\text { Head's Household } \\
\text { age }\end{array}$ & $\begin{array}{l}\text { Number of children } \\
\text { per household }\end{array}$ & All regions \\
\hline $\begin{array}{l}\text { Weight for age } \\
\text { (malnutrition) }\end{array}$ & 0.79 & 2.44 & 10.42 & 15.33 & 5.40 & 37.27 & 23.57 & 4.73 & 35.26 \\
\hline $\begin{array}{l}\text { Height for age } \\
\text { (stunting) }\end{array}$ & 0.16 & 25.49 & 11.71 & 43.58 & 8.01 & 4.76 & 2.55 & 3.71 & 22.31 \\
\hline $\begin{array}{l}\text { Weight for height } \\
\text { (Emaciation) }\end{array}$ & 16.05 & 5.16 & 3.72 & 4.97 & 7.42 & 7.35 & 7.89 & 47.39 & 22.50 \\
\hline
\end{tabular}

based on Table 3 such us this two variables are strongly significant in explaining malnutrition of Tunisian's children. For stunting situation, we can see that the main determinant of delays in children growth is the family economic situation and head's household education and that this finding is supported by the significance of these variables at the $5 \%$ threshold in Logit regression. Then, the number of child per household is an important factor explaining emaciation of early childhood in Tunisia. Furthermore, we note that the variables region is significant in explaining nutritional status of children meaning that people living in the west are favored than the rest of citizens (Table 10 Appendix).

\section{Discussions}

Our results show that inequalities in terms of nutritional conditions are largely explained by economic indicators such us wealth index or number of children per household. These variables are different between eastern and western regions (Table 10 Appendix) which explains differences in terms of coverage and dissimilarity in access to basic nutritional services presented in Table 4.

In one hand, the western regions are of low demographic concentration compared to the coastal regions. On the other hand, the households living in these regions are mostly in rural areas which are characterized by a delicate financial situation and a low income (In some families no one have a permanent work). For example, the poorest family income represent $58.08 \%$ in Sidi Bouzid against only $10.06 \%$ in Center east (Table 10 Appendix). In addition to the lack of investment in these regions (compared to coastal regions which seduce investors), basic infrastructure and public health institutions are inexistent or under developed(for example access to potable water is $70.22 \%$ in district Tunisia but does not exceed $36 \%$ in Sidi Bouzid or $44.59 \%$ in Kairouan (Table 10 Appendix). Moreover theses regions are characterized by a low level of parents' education reducing chance for child to receive appropriate vaccine and nutrition. For example, women who have not received any training account for roughly 33\% in kairouan and sidi sidi bouzid while in the center it is not more than $7 \%$.

All these conditions influence the environment in which the child is born and is obliged to survive in a difficult nutritional situation affecting its intellectual capacities and productive skills. In rural area $13.78 \%$ of children are exposed to growth problem against $7.84 \%$ in urban regions (Table 1 ). These results can be explained by inefficient intervention of public authorities to overcome social problems and reduce differences of inequality between regions. In developing countries, such as Tunisia, the state is in the center of economy and public sector still dominates. So, inequality in access to basic service is largely explained by absence of an efficient and equitable policy of income redistribution by public authorities on the basis of a fiscal policy driven by high rates against the rich and subsidies addressed to the poorest agents. Private sector is still underdeveloped or embryonic and its role of redistribution of profits is non-existent or negligible because of inappropriate institutional framework or absence of good governance. Regions that are characterized by problem of economic growth, high levels of poverty and lack of infrastructure are characterized by childhood opportunity inequalities, reduced feelings of Non-membership and criminal in adulthood. Many statistics on terrorism consider Tunisia as leader in terms of terrorism explaining this phenomenon by poverty, lack of social equity and unequal opportunities. These latter can be more serious in adulthood because of the differences in efforts which themselves depend on circumstances uncontrollable by agents.

In order to test robustness of our findings, we present significance of each variables using Logit model regression by region in the appendices (Table 16 Appendix). We mainly conclude that head's household education, family income and head's household age matters in disadvantaged areas but does not arise in more developed regions in explaining nutritional 
Table 6 Results of logit model (Health)

\begin{tabular}{|c|c|c|c|c|c|c|c|c|c|c|c|c|}
\hline \multirow{3}{*}{$\begin{array}{l}\text { Endogenous variables } \\
\text { Exogenous Variables }\end{array}$} & \multicolumn{6}{|c|}{ Tunisia 1982-2012 } & \multicolumn{6}{|c|}{ Tunisia 2011-2012 } \\
\hline & \multicolumn{2}{|c|}{ Prenatal care } & \multicolumn{2}{|c|}{ Blood samples } & \multicolumn{2}{|c|}{ Postnatal care } & \multicolumn{2}{|c|}{ Prenatal care } & \multicolumn{2}{|c|}{ Blood samples } & \multicolumn{2}{|c|}{ Postnatal care } \\
\hline & Coef & $P$-Value & Coef & $P$-Value & Coef & $P$-Value & Coef & $P$-Value & Coef & $P$-Value & Coef & $P$-Value \\
\hline Gender & .074 & 0.344 & .099 & 0.209 & .011 & 0.901 & -.907 & 0.056 & .002 & 0.993 & -.115 & 0.359 \\
\hline Residence & -.267 & 0.006 & -.243 & 0.012 & -.275 & 0.017 & -.272 & 0.616 & .125 & 0.711 & -.149 & 0.337 \\
\hline H-h Education & -.250 & 0.057 & -.296 & 0.025 & -.122 & 0.457 & 1.28 & 0.021 & .146 & 0.738 & .209 & 0.360 \\
\hline Wealth index & -.008 & 0.931 & .012 & 0.895 & .192 & 0.097 & .570 & 0.337 & .457 & 0.193 & .372 & 0.015 \\
\hline $\mathrm{H}$-h gender & .389 & 0.039 & .386 & 0.043 & .368 & 0.122 & 1.35 & 0.068 & .652 & 0.271 & .045 & 0.888 \\
\hline Household size & .345 & 0.000 & .333 & 0.000 & .331 & 0.000 & -.205 & 0.245 & -.144 & 0.225 & .083 & 0.197 \\
\hline Number of children(2-14) & -.750 & 0.000 & -.741 & 0.000 & -.676 & 0.000 & -.423 & 0.071 & -.214 & 0.160 & -.161 & 0.043 \\
\hline $\mathrm{H}$-h age & -.112 & 0.000 & -.111 & 0.000 & -.107 & 0.000 & .037 & 0.122 & .012 & 0.452 & -.013 & 0.073 \\
\hline Constant & 3.27 & 0.000 & 3.19 & 0.000 & 2.07 & 0.000 & 2.27 & 0.074 & 2.41 & 0.013 & .368 & 0.462 \\
\hline Obs & 4200 & & 4200 & & 4200 & & 1059 & & 1059 & & 1059 & \\
\hline Prob > chi2 & 0.0000 & & 0.0000 & & 0.0000 & & 0.0000 & & 0.0059 & & 0.0122 & \\
\hline
\end{tabular}

insufficiency. Results are largely similar to our main regressions and confirm our interpretations and conclusions.

\section{Access to health care services before, after, and during pregnancy}

As mentioned above, the use of prenatal and postnatal care and during pregnancy are very important for the development of the child. So, similarly to our demarche in subsection 4.1 in the case of nutritional status of Tunisian childhood, we begin by presenting results of logit model in order to specify principal determinants of each healthy indicator.

\section{Results}

Table 6 shows the results of Logit model regression when we consider health indicator variables as dependant variables. The second column shows that coefficients associated to the variables residence, head's household education, gender and age, household size, and numbers of children are statistically significant at the $10 \%$ threshold in explaining access to prenatal care during the full sample period. In 2012, residence and household's age become insignificant but we can see that male children have less possible access to prenatal service(the coefficient of gender variable is statistically significant at conventional level). Concerning blood sample during the period 19822012, we note that access to this service is totally explained by the same determinants of prenatal services but no variables are significant in 2012. Finally, access to post natal care are largely explained by family income, number of children between 2 and 14 years and head's household age for our two subsample in addition to insignificant role of residence and household size in 2012 compared to the full sample.

Table 7 shows that at the national level, access to the prenatal services is seen to be very limited, with $24.66 \%$ of mothers in Tunisia received prenatal services during the period from 1982 until 2012. In other words, almost a quarter of Tunisian children have the opportunity to access to prenatal care services. Therefore, D-index (which measures inequality) is high meaning that $27.95 \%$ of Tunisian prenatal services are granted in an unequal manner and need to be redistributed equally to ensure equal opportunities (Corresponding HOI is small and does not exceed $17.77 \%)$. Similarly for the other indicators, it was found that $23.85 \%$ of mothers received blood samples

Table 7 Coverage rate of access to health indicators by regions (1982-2012)

\begin{tabular}{llll}
\hline Tunisia 1982-2012 & $\begin{array}{l}\text { Access to } \\
\text { prenatal care \% }\end{array}$ & $\begin{array}{l}\text { Access to } \\
\text { blood samples \% }\end{array}$ & $\begin{array}{l}\text { Access to } \\
\text { postnatal care \% }\end{array}$ \\
\hline Great Tunis & $20.98(38.84)$ & $20.66(39.18)$ & $12.40(44.37)$ \\
North East & $24.40(33.32)$ & $23.37(33.59)$ & $17.23(\mathrm{nn} .29)$ \\
North West & $21.51(22.48)$ & $20.54(21.74)$ & $12.40(30.19)$ \\
Center East & $22.59(36.95)$ & $21.54(36.40)$ & $18.20(39.24)$ \\
Kasserine & $25.19(27.25)$ & $23.91(29.18)$ & $16.53(31.86)$ \\
Kairouan & $32.32(21.66)$ & $31.78(21.79)$ & $16.16(24.21)$ \\
Sidi Bouzid & $24.13(27.49)$ & $22.70(26.04)$ & $12.50(31.51)$ \\
South East & $28.81(25.10)$ & $28.60(25.49)$ & $12.07(18.19)$ \\
South West & $25.42(28.59)$ & $24.69(28.23)$ & $12.10(30.79)$ \\
Tunisia & $24.66(27.95)$ & $23.85(28.02)$ & $14.33(30.76)$ \\
\hline
\end{tabular}

Numbers in parenthesis are corresponding D-index values 
Table $\mathbf{8}$ Coverage rate of access to health indicators by regions (2011-2012)

\begin{tabular}{llll}
\hline Tunis 2011-2012 & $\begin{array}{l}\text { Access to } \\
\text { prenatal care \% }\end{array}$ & $\begin{array}{l}\text { Access to blood } \\
\text { samples \% }\end{array}$ & $\begin{array}{l}\text { Access to } \\
\text { postnatal care \% }\end{array}$ \\
\hline Coast regions & $98.66(.523)$ & $96.00(.834)$ & $61.40(3.95)$ \\
Interior regions & $96.99(1.65)$ & $93.24(2.06)$ & $52.34(6.27)$ \\
Male & $97.06(1.39)$ & $94.67(1.60)$ & $55.41(4.62)$ \\
Female & $98.63(.693)$ & $94.55(1.20)$ & $58.36(5.71)$ \\
Urban & $98.50(.827)$ & $96.00(.923)$ & $58.06(3.73)$ \\
Rural & $96.94(1.18)$ & $92.79(1.42)$ & $55.24(6.95)$ \\
Nord & $98.21(.710)$ & $94.91(1.28)$ & $61.83(5.52)$ \\
Center & $98.10(.771)$ & $94.56(1.46)$ & $63.74(6.76)$ \\
South & $93.97(3.45)$ & $94.32(2.30)$ & $44.17(6.76)$ \\
Tunisia & $97.82(.977)$ & $94.61(1.32)$ & $56.84(4.74)$ \\
\hline
\end{tabular}

Numbers in parenthesis are corresponding D-index values

to detect nutritional deficiencies in their offspring, and only $14.33 \%$ benefited from postnatal services such as midwifery or trained staff.

Despite the limited coverage rates in previous decades, the Tunisian Government has greatly improved its prenatal and postnatal services during the last few years. Table 8 shows that $97.82 \%$ and $94.61 \%$ of Tunisian childhood have access to prenatal care and blood sample, respectively, in 2012 with a small dissimilarity index $(0.977 \%)$. But, the level of access to postnatal services remains low since half of the children do not have access to this service (only 56.84\% have access to postnatal services).

Table 7 shows that there are important disparities between regions and socio-demographic neighborhoods in Tunisia during the period 1982-2012. This table shows that for access to prenatal services, most of the eastern regions of the country in addition to Kairoaun have higher coverage rate than the rest of the regions, ie children of these regions have most opportunity to access to these services compared to other regions. For example in Kairouan 32.32\%, and in the South East $28.81 \%$ of child or (mother) received prenatal care (vaccinations), while in North west $21.51 \%$ of concerned population have the chance to receive the same services with a high dissimilarity index in eastern region (for example Dindex in center east is $36.95 \%$ which is very high for a country in the Mediterranean basin) meaning that most of childhood have not received the same opportunities to benefit from this service. In 2012, access to prenatal is improved in all regions approaching $100 \%$ and disparities are reduced with a small advantage of cost regions compared to interior regions (and urban region are more covered by this service). If we decompose Tunisian area into three great zones, we feel that southern governorates are less favored in access to prenatal services $(\mathrm{HOI}=93.97 \%$ even that D-index is small and do not exceed $4 \%$ (Table 8).

For the other indicators, regional disparities in access to post-natal services and blood sampling are discarded. Indeed, for blood sampling, Sidi Bouzid and the South West have the lowest coverage rates and they also remain for the postnatal indicator during the full sample period. For the last indicator (postnatal care), only the Central East and North East regions have the highest rate. In 2012, there are no great differences between male and female in access to blood sample and post natal services. But, coast and urban regions are more covered by these services than others zones especially southern and interior regions.

To identify exogenous variable that contributes more to differences of inequality we presented Shapley decomposition results (Table 9). The main finding is that the variable "head's household age" is the most important to explain inequality of access to all health services during the last three decades. Surprisingly, this variable is the most significant in explaining discrepancy in terms of access to health services. Thus, an inequality grows over time and become very serious in adulthood or when agents become older. This reality can be, in part, explained by education level of the head's household but may also be the consequence of an inappropriate health system that does not care for the elderly. Many households are not

Table 9 Decomposition of dissimilarity in access to health care services by circumstances

\begin{tabular}{|c|c|c|c|c|c|c|c|c|c|}
\hline Tunisia: 1982-2012 & Gender & Residence & $\begin{array}{l}\text { Head's household } \\
\text { education }\end{array}$ & $\begin{array}{l}\text { Wealth } \\
\text { index }\end{array}$ & $\begin{array}{l}\text { Household } \\
\text { gender }\end{array}$ & $\begin{array}{l}\text { Household } \\
\text { size }\end{array}$ & Household age & $\begin{array}{l}\text { Number of children } \\
\text { per household }\end{array}$ & All regions \\
\hline Prenatal care & .716 & 4.38 & 2.03 & 2.03 & 1.82 & 8.44 & 44.67 & 30.13 & 5.76 \\
\hline Blood Samples & 1.02 & 3.88 & 1.85 & 1.66 & 1.74 & 8.72 & 44.33 & 30.39 & .363 \\
\hline Postnatal Care & .221 & 3.16 & 2.86 & .248 & 2.05 & 8.84 & 46.78 & 28.21 & 7.59 \\
\hline \multicolumn{10}{|l|}{ Tunisia: 2012} \\
\hline Prenatal care & 10.61 & 5.88 & 13.47 & 12.22 & 6.64 & 15.28 & 2.60 & 25.56 & 7.69 \\
\hline Blood Samples & .296 & 13.31 & 3.35 & 20.93 & 3.58 & 19.08 & 2.06 & 25.84 & 11.51 \\
\hline Postnatal Care & 4.62 & 4.16 & 8.29 & 21.89 & 1.94 & 6.58 & 13.42 & 12.48 & 26.57 \\
\hline
\end{tabular}


part of the health insurance system and spend most of their working lives in black jobs. This fragile labor situation, generally without social contributions, leads to retirement age without social security benefits. Head's household age is again important in explaining access to post natal care but the variable "number of children (2-14)" prevails in 2012 in explaining opportunity' inequality in access to prenatal care and blood samples. In addition, we remark that family income begins to become important determinant of health services access in lat years. These conclusions are largely supported by results obtained by logit model regression (Table 6).

\section{Discussions}

In fact, mothers who need more health care before, during and after pregnancy are in areas of low demographic or rural concentration, especially in the western and Southern regions and in Sidi Bouzid as we have already seen. Despite the similar level of coverage in some cases, the qualification of the officers performing this service differs widely across regions (Table 15 Appendix). Coverage rates are smaller compared to others regions. In addition residence, household education and wealth income are statistically significant in explaining access to health services in many regions of the south and west which is not the case for eastern region (Table 17 Appendix). Moreover, the infrastructure in these interior governorates is almost not-existent; hence moving for diagnosis is difficult for too old mothers. Health information and advices for the mother during the pregnancy phase are considered as a lever for the future development of the babies. However, women living in these areas have low levels of education. As a result, the prevalence of diseases caused by lack of health care has been observed among children from the poorest households and the least educated and elderly mothers.

As a conclusion, families characterized by numerous children and older head's household are more exposed to health problems in all the whole territory. In particular, the southern region are less favored in access to prenatal and postnatal care services in addition to the qualification of personnel ensuring this task. This fact can be explained by the absence of health schools and university hospitals in addition to specialized medicine in these regions.

\section{Conclusion and policy implications}

Deficits and inequality early in life tend to accumulate and compound and lead to persistent shortfalls in human capital [32]. Based on a relatively few circumstances, which are entirely beyond of their control, this paper has shown that, Tunisian children face unequal opportunities to develop in terms of health, nutrition, cognitive, social, and emotional development. Likewise, we found that, parents' education, wealth, age of household head and geographic factors as key factors determining child development outcomes.

Unequal provision of government services across different regions could contribute to geographic differences. Thus, it was recommended, among other things, that the government should, make periodic surveys on health status, on health care utilization, for financial reasons, Furthermore, to reduce financial constraint on access to care, through better targeting of the poor who should benefit from free medical assistance.

It was further recommended that efforts should be made by policymakers to help and encourage doctors to settle specially in disadvantaged region. Finally, and, on the institutional side: the policymakers should pursue new plan to reduce social and regional inequalities in access to health service in particular in rural areas.

As a final recommendation, Tunisian State must restructure the pension funds and provide free services to children whose heads of households are not members of the social funds. This policy can help reducing inequalities of opportunity in adult age and so reducing criminals and terrorism and enhances growth and development through increased productivity.

\section{Endnotes}

${ }^{1}$ In 2006, WHO published growth standards for weight and height to replace the 1977 National Center of Health Statistics (NCHS).

${ }^{2}$ Chantreuil and Trannoy [28] and Sastre et Trannoy [29] applied Shapley decomposition methodology to explain only income inequality but Shorrocks [13] has shown that such a decomposition could be applied to any function.

${ }^{3}$ Each of the three indicators of nutritional status can be expressed in units of standard deviations (reduced deviation) from the median of the reference population. The reference population used in this paper is based on the WHO growth standards. http://www.who.int/ childgrowth/standards/second_set/technical_report_2. pdf. (Table A.3; A.4 and A.5 in appendix)

${ }^{4}$ When $P$-Value is less than $5 \%$ we can reject the null hypothesis meaning that the coefficient is not significant. So, we accept alternative hypothesis which means that the variable is statistically significant in explaining dependent variable. 


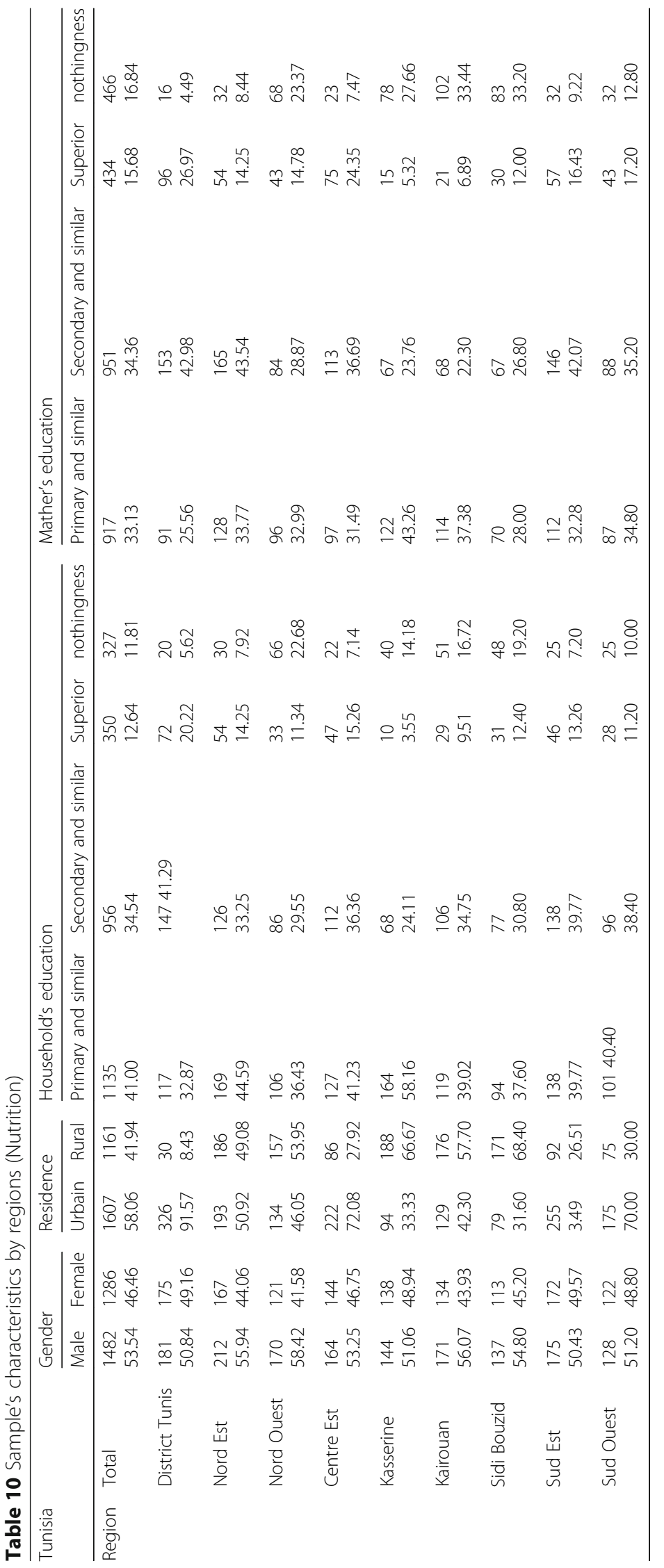




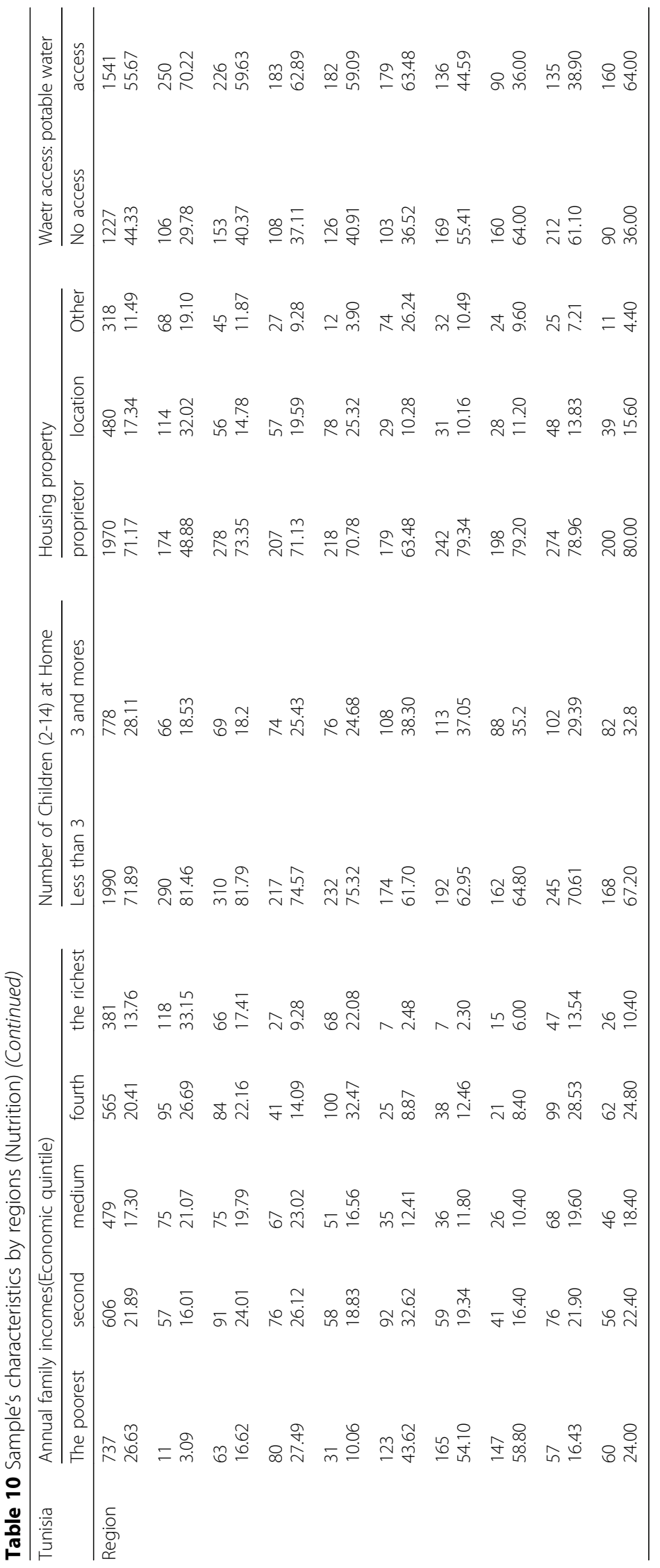




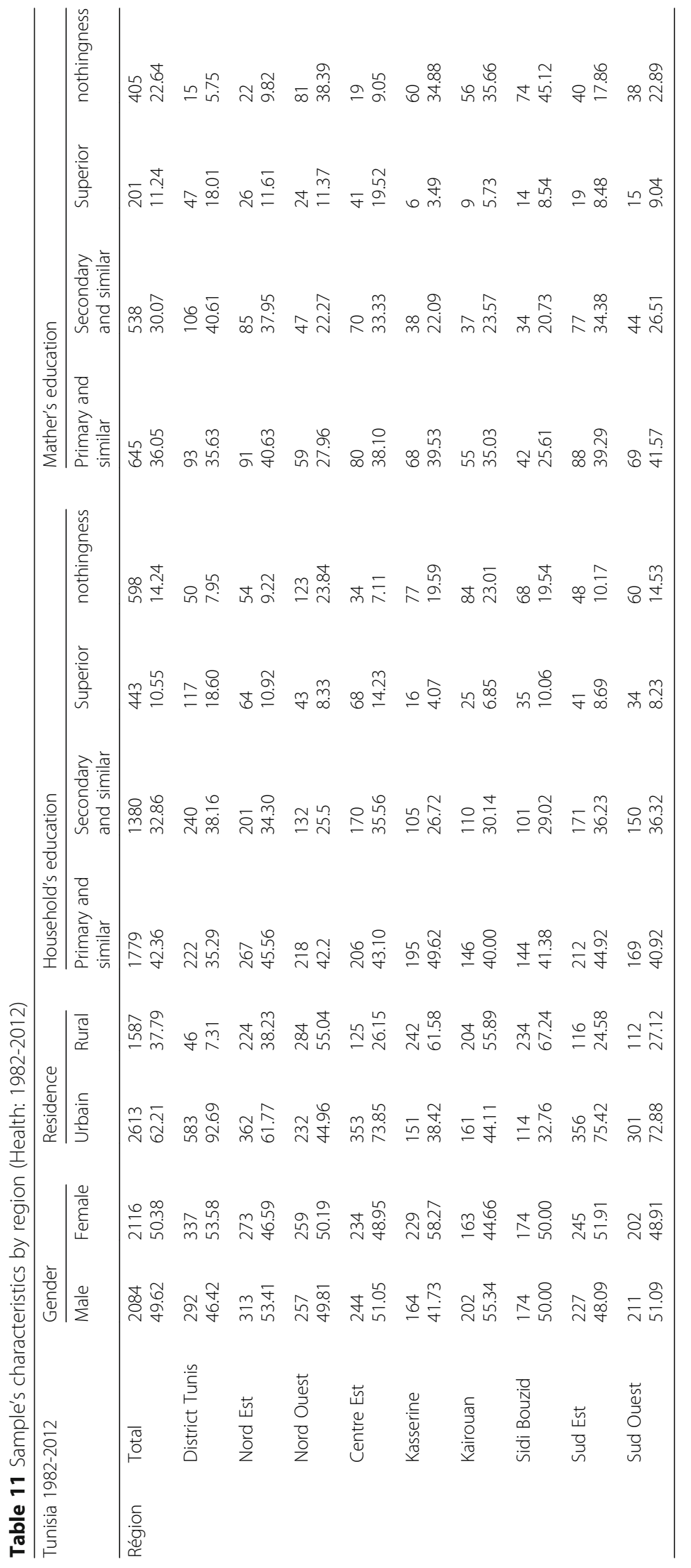




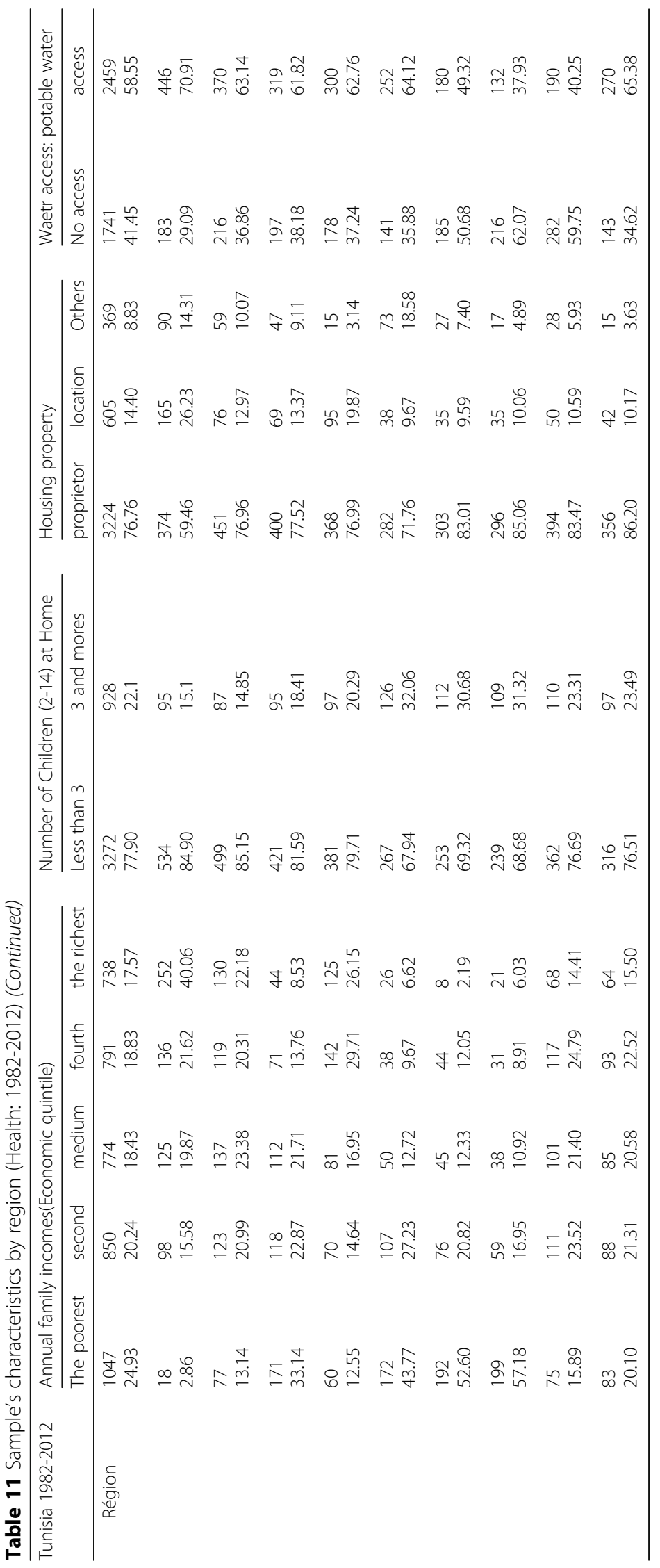




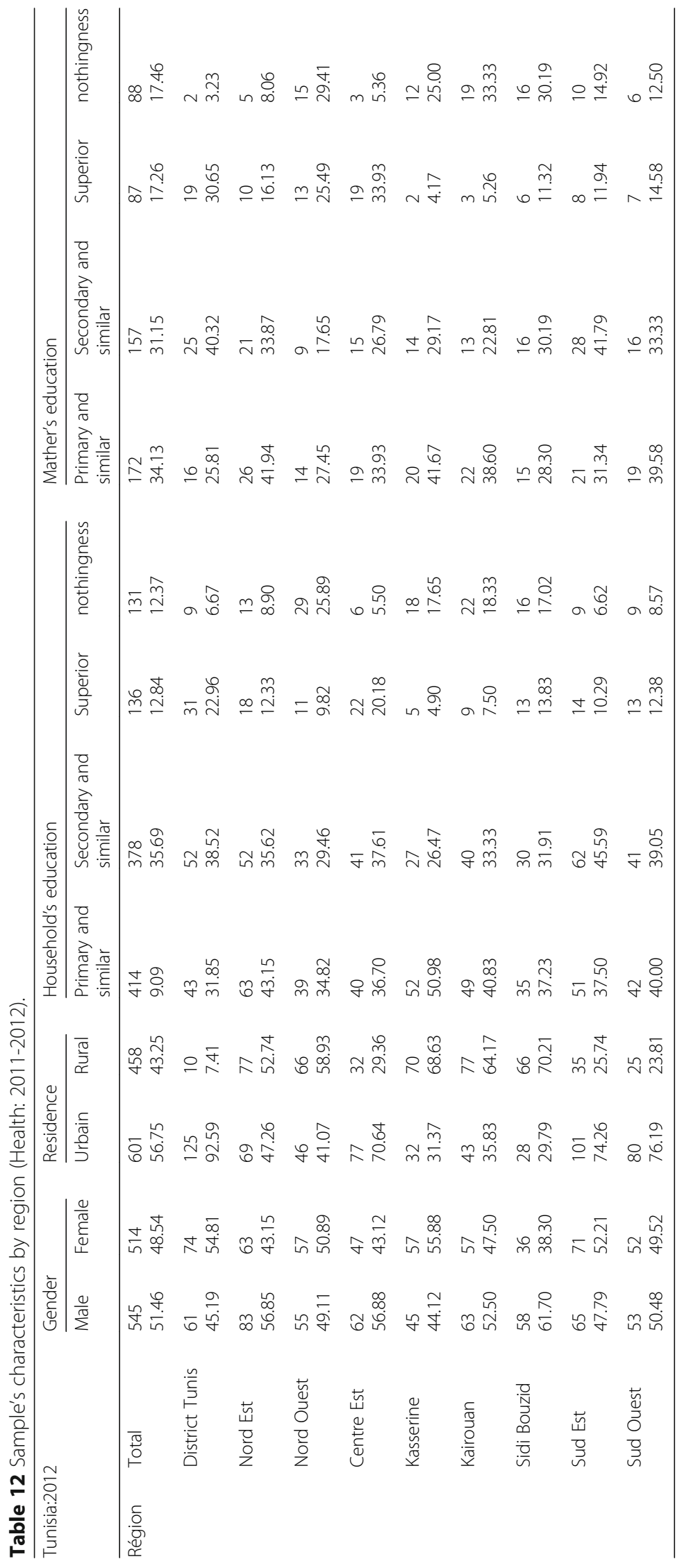




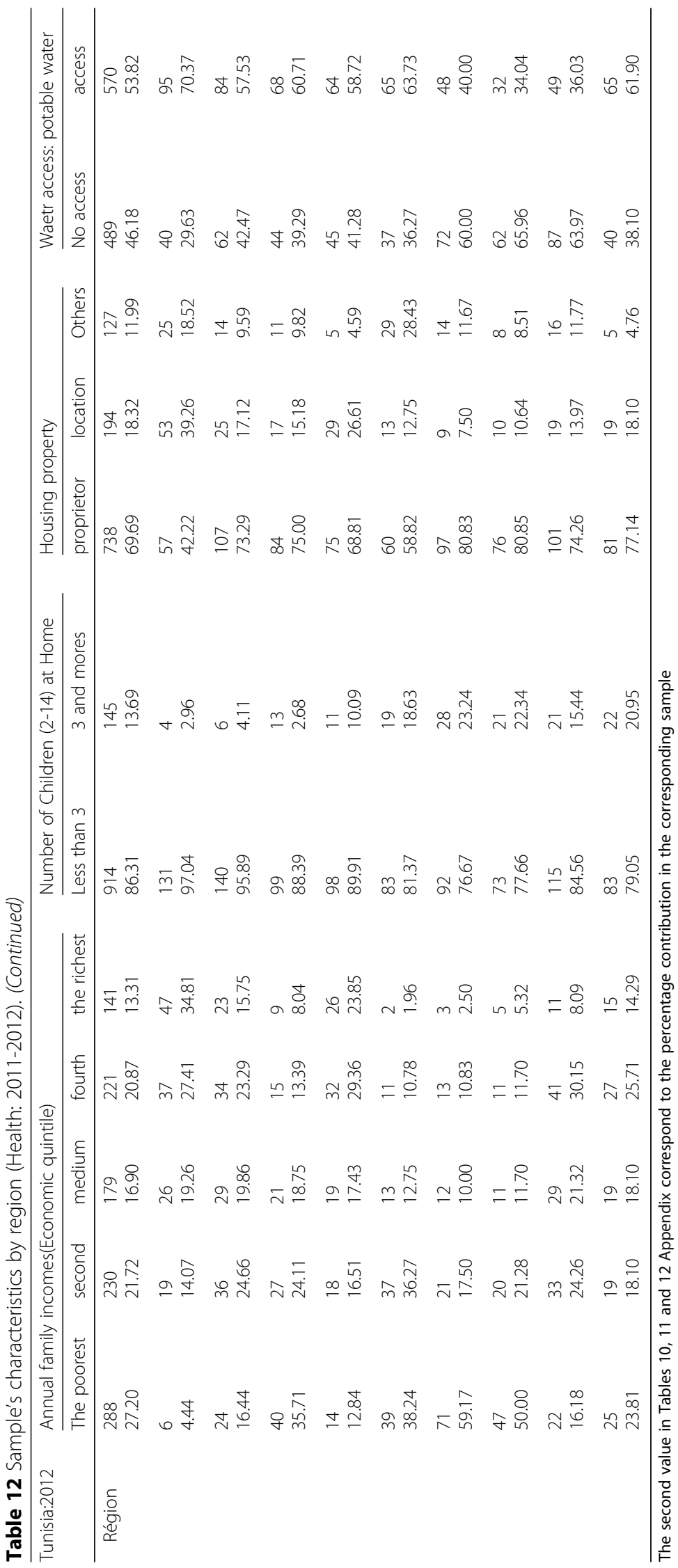




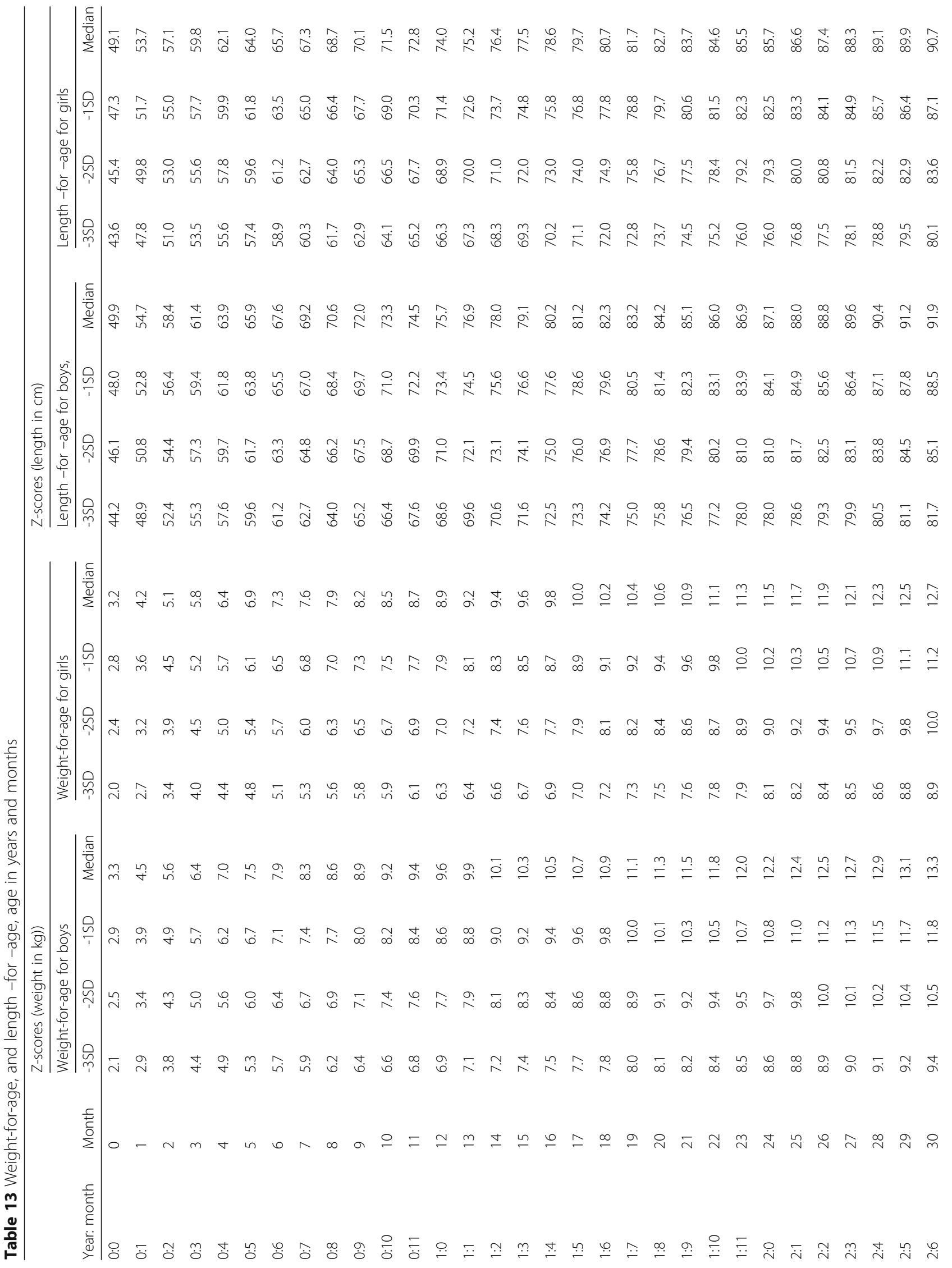




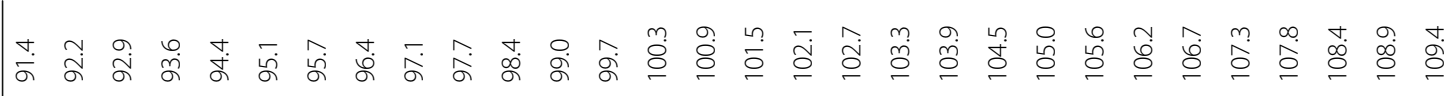
ڤ

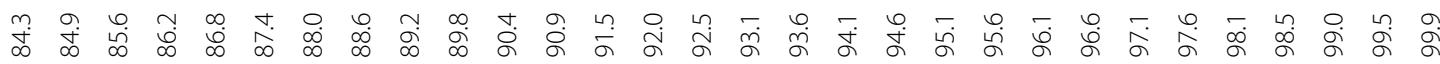

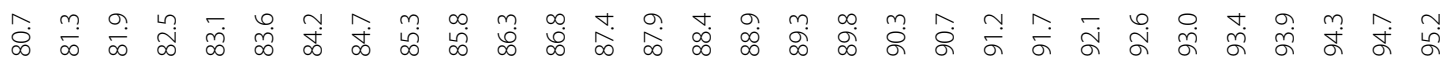
సं

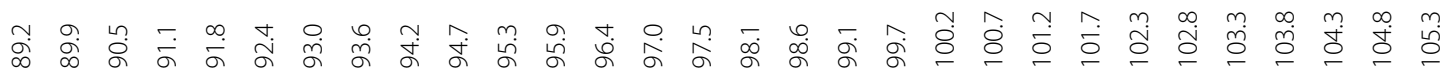

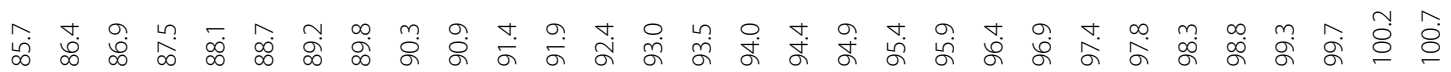

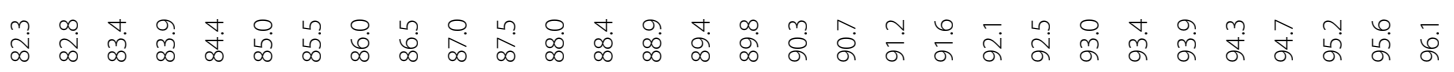

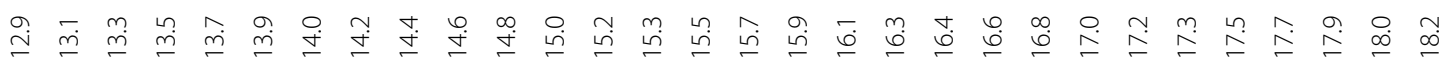

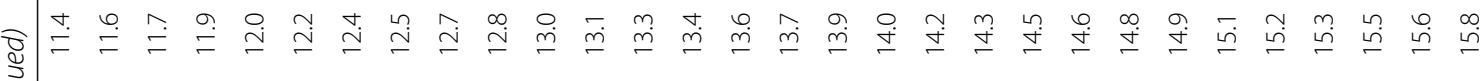

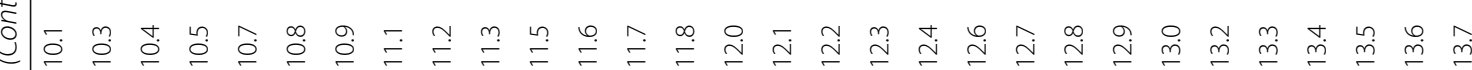

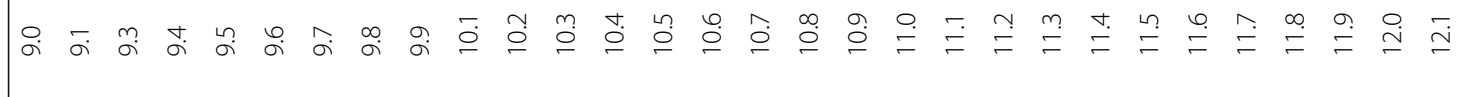

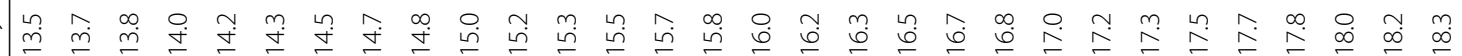
$\underset{\mathscr{D}}{\mathscr{8}}$

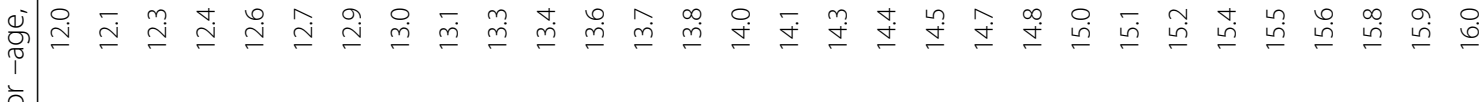

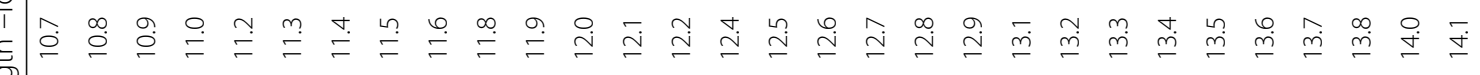
น 草

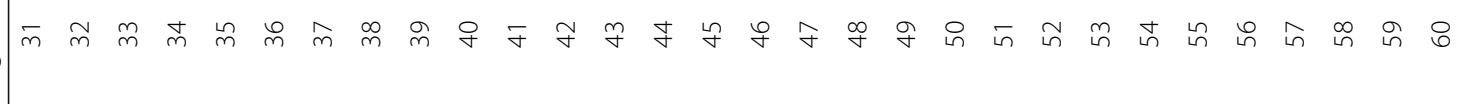

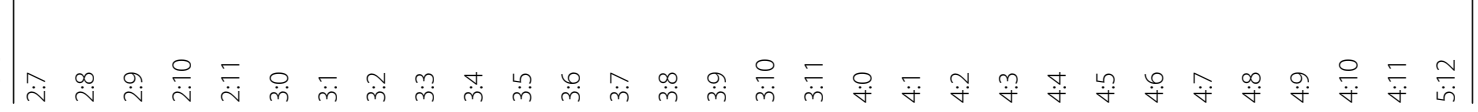


Table 14 Weight-for-length standards

\begin{tabular}{|c|c|c|c|c|c|c|c|c|}
\hline \multirow[b]{3}{*}{ Length $(\mathrm{cm})$} & \multicolumn{8}{|c|}{ Z-scores (weight in kg) } \\
\hline & \multicolumn{4}{|c|}{ Weight-for-length for boys } & \multicolumn{4}{|c|}{ Weight-for-length for Girls } \\
\hline & $-3 S D$ & $-2 S D$ & $-1 S D$ & Median & $-3 S D$ & $-2 S D$ & $-1 S D$ & Median \\
\hline 45.0 & 1.9 & 2.0 & 2.2 & 2.4 & 1.9 & 2.1 & 2.3 & 2.5 \\
\hline 45.5 & 1.9 & 2.1 & 2.3 & 2.5 & 2.0 & 2.1 & 2.3 & 2.5 \\
\hline 46.0 & 2.0 & 2.2 & 2.4 & 2.6 & 2.0 & 2.2 & 2.4 & 2.6 \\
\hline 46.5 & 2.1 & 2.3 & 2.5 & 2.7 & 2.1 & 2.3 & 2.5 & 2.7 \\
\hline 47.0 & 2.1 & 2.3 & 2.5 & 2.8 & 2.2 & 2.4 & 2.6 & 2.8 \\
\hline 47.5 & 2.2 & 2.4 & 2.6 & 2.9 & 2.2 & 2.4 & 2.6 & 2.9 \\
\hline 48.0 & 2.3 & 2.5 & 2.7 & 2.9 & 2.3 & 2.5 & 2.7 & 3.0 \\
\hline 48.5 & 2.3 & 2.6 & 2.8 & 3.0 & 2.4 & 2.6 & 2.8 & 3.1 \\
\hline 49.0 & 2.4 & 2.6 & 2.9 & 3.1 & 2.4 & 2.6 & 2.9 & 3.2 \\
\hline 49.5 & 2.5 & 2.7 & 3.0 & 3.2 & 2.5 & 2.7 & 3.0 & 3.3 \\
\hline 50.0 & 2.6 & 2.8 & 3.0 & 3.3 & 2.6 & 2.8 & 3.1 & 3.4 \\
\hline 50.5 & 2.7 & 2.9 & 3.1 & 3.4 & 2.7 & 2.9 & 3.2 & 3.5 \\
\hline 51.0 & 2.7 & 3.0 & 3.2 & 3.5 & 2.8 & 3.0 & 3.3 & 3.6 \\
\hline 51.5 & 2.8 & 3.1 & 3.3 & 3.6 & 2.8 & 3.1 & 3.4 & 3.7 \\
\hline 52.0 & 2.9 & 3.2 & 3.5 & 3.8 & 2.9 & 3.2 & 3.5 & 3.8 \\
\hline 52.5 & 3.0 & 3.3 & 3.6 & 3.9 & 3.0 & 3.3 & 3.6 & 3.9 \\
\hline 53.0 & 3.1 & 3.4 & 3.7 & 4.0 & 3.1 & 3.4 & 3.7 & 4.0 \\
\hline 53.5 & 3.2 & 3.5 & 3.8 & 4.1 & 3.2 & 3.5 & 3.8 & 4.2 \\
\hline 54.0 & 3.3 & 3.6 & 3.9 & 4.3 & 3.3 & 3.6 & 3.9 & 4.3 \\
\hline 54.5 & 3.4 & 3.7 & 4.0 & 4.4 & 3.4 & 3.7 & 4.0 & 4.4 \\
\hline 55.0 & 3.6 & 3.8 & 4.2 & 4.5 & 3.5 & 3.8 & 4.2 & 4.5 \\
\hline 55.5 & 3.7 & 4.0 & 4.3 & 4.7 & 3.6 & 3.9 & 4.3 & 4.7 \\
\hline 56.0 & 3.8 & 4.1 & 4.4 & 4.8 & 3.7 & 4.0 & 4.4 & 4.8 \\
\hline 56.5 & 3.9 & 4.2 & 4.6 & 5.0 & 3.8 & 4.1 & 4.5 & 5.0 \\
\hline 57.0 & 4.0 & 4.3 & 4.7 & 5.1 & 3.9 & 4.3 & 4.6 & 5.1 \\
\hline 57.5 & 4.1 & 4.5 & 4.9 & 5.3 & 4.0 & 4.4 & 4.8 & 5.2 \\
\hline 58.0 & 4.3 & 4.6 & 5.0 & 5.4 & 4.1 & 4.5 & 4.9 & 5.4 \\
\hline 58.5 & 4.4 & 4.7 & 5.1 & 5.6 & 4.2 & 4.6 & 5.0 & 5.5 \\
\hline 59.0 & 4.5 & 4.8 & 5.3 & 5.7 & 4.3 & 4.7 & 5.1 & 5.6 \\
\hline 59.5 & 4.6 & 5.0 & 5.4 & 5.9 & 4.4 & 4.8 & 5.3 & 5.7 \\
\hline 60.0 & 4.7 & 5.1 & 5.5 & 6.0 & 4.5 & 4.9 & 5.4 & 5.9 \\
\hline 60.5 & 4.8 & 5.2 & 5.6 & 6.1 & 4.6 & 5.0 & 5.5 & 6.0 \\
\hline 61.0 & 4.9 & 5.3 & 5.8 & 6.3 & 4.7 & 5.1 & 5.6 & 6.1 \\
\hline 61.5 & 5.0 & 5.4 & 5.9 & 6.4 & 4.8 & 5.2 & 5.7 & 6.3 \\
\hline 62.0 & 5.1 & 5.6 & 6.0 & 6.5 & 4.9 & 5.3 & 5.8 & 6.4 \\
\hline 62.5 & 5.2 & 5.7 & 6.1 & 6.7 & 5.0 & 5.4 & 5.9 & 6.5 \\
\hline 63.0 & 5.3 & 5.8 & 6.2 & 6.8 & 5.1 & 5.5 & 6.0 & 6.6 \\
\hline 63.5 & 5.4 & 5.9 & 6.4 & 6.9 & 5.2 & 5.6 & 6.2 & 6.7 \\
\hline 64.0 & 5.5 & 6.0 & 6.5 & 7.0 & 5.3 & 5.7 & 6.3 & 6.9 \\
\hline 64.5 & 5.6 & 6.1 & 6.6 & 7.1 & 5.4 & 5.8 & 6.4 & 7.0 \\
\hline 65.0 & 5.7 & 6.2 & 6.7 & 7.3 & 5.5 & 5.9 & 6.5 & 7.1 \\
\hline 65.5 & 5.8 & 6.3 & 6.8 & 7.4 & 5.5 & 6.0 & 6.6 & 7.2 \\
\hline
\end{tabular}


Table 14 Weight-for-length standards (Continued)

\begin{tabular}{|c|c|c|c|c|c|c|c|c|}
\hline 66.0 & 5.9 & 6.4 & 6.9 & 7.5 & 5.6 & 6.1 & 6.7 & 7.3 \\
\hline 66.5 & 6.0 & 6.5 & 7.0 & 7.6 & 5.7 & 6.2 & 6.8 & 7.4 \\
\hline 67.0 & 6.1 & 6.6 & 7.1 & 7.7 & 5.8 & 6.3 & 6.9 & 7.5 \\
\hline 67.5 & 6.2 & 6.7 & 7.2 & 7.9 & 5.9 & 6.4 & 7.0 & 7.6 \\
\hline 68.0 & 6.3 & 6.8 & 7.3 & 8.0 & 6.0 & 6.5 & 7.1 & 7.7 \\
\hline 68.5 & 6.4 & 6.9 & 7.5 & 8.1 & 6.1 & 6.6 & 7.2 & 7.9 \\
\hline 69.0 & 6.5 & 7.0 & 7.6 & 8.2 & 6.1 & 6.7 & 7.3 & 8.0 \\
\hline 69.5 & 6.6 & 7.1 & 7.7 & 8.3 & 6.2 & 6.8 & 7.4 & 8.1 \\
\hline 70.0 & 6.6 & 7.2 & 7.8 & 8.4 & 6.3 & 6.9 & 7.5 & 8.2 \\
\hline 70.5 & 6.7 & 7.3 & 7.9 & 8.5 & 6.4 & 6.9 & 7.6 & 8.3 \\
\hline 71.0 & 6.8 & 7.4 & 8.0 & 8.6 & 6.5 & 7.0 & 7.7 & 8.4 \\
\hline 71.5 & 6.9 & 7.5 & 8.1 & 8.8 & 6.5 & 7.1 & 7.7 & 8.5 \\
\hline 72.0 & 7.0 & 7.6 & 8.2 & 8.9 & 6.6 & 7.2 & 7.8 & 8.6 \\
\hline 72.5 & 7.1 & 7.6 & 8.3 & 9.0 & 6.7 & 7.3 & 7.9 & 8.7 \\
\hline 73.0 & 7.2 & 7.7 & 8.4 & 9.1 & 6.8 & 7.4 & 8.0 & 8.8 \\
\hline 73.5 & 7.2 & 7.8 & 8.5 & 9.2 & 6.9 & 7.4 & 8.1 & 8.9 \\
\hline 74.0 & 7.3 & 7.9 & 8.6 & 9.3 & 6.9 & 7.5 & 8.2 & 9.0 \\
\hline 74.5 & 7.4 & 8.0 & 8.7 & 9.4 & 7.0 & 7.6 & 8.3 & 9.1 \\
\hline 75.0 & 7.5 & 8.1 & 8.8 & 9.5 & 7.1 & 7.7 & 8.4 & 9.1 \\
\hline 75.5 & 7.6 & 8.2 & 8.8 & 9.6 & 7.1 & 7.8 & 8.5 & 9.2 \\
\hline 76.0 & 7.6 & 8.3 & 8.9 & 9.7 & 7.2 & 7.8 & 8.5 & 9.3 \\
\hline 76.5 & 7.7 & 8.3 & 9.0 & 9.8 & 7.3 & 7.9 & 8.6 & 9.4 \\
\hline 77.0 & 7.8 & 8.4 & 9.1 & 9.9 & 7.4 & 8.0 & 8.7 & 9.5 \\
\hline 77.5 & 7.9 & 8.5 & 9.2 & 10.0 & 7.4 & 8.1 & 8.8 & 9.6 \\
\hline 78.0 & 7.9 & 8.6 & 9.3 & 10.1 & 7.5 & 8.2 & 8.9 & 9.7 \\
\hline 78.5 & 8.0 & 8.7 & 9.4 & 10.2 & 7.6 & 8.2 & 9.0 & 9.8 \\
\hline 79.0 & 8.1 & 8.7 & 9.5 & 10.3 & 7.7 & 8.3 & 9.1 & 9.9 \\
\hline 79.5 & 8.2 & 8.8 & 9.5 & 10.4 & 7.7 & 8.4 & 9.1 & 10.0 \\
\hline 80.0 & 8.2 & 8.9 & 9.6 & 10.4 & 7.8 & 8.5 & 9.2 & 10.1 \\
\hline 80.5 & 8.3 & 9.0 & 9.7 & 10.5 & 7.9 & 8.6 & 9.3 & 10.2 \\
\hline 81.0 & 8.4 & 9.1 & 9.8 & 10.6 & 8.0 & 8.7 & 9.4 & 10.3 \\
\hline 81.5 & 8.5 & 9.1 & 9.9 & 10.7 & 8.1 & 8.8 & 9.5 & 10.4 \\
\hline 82.0 & 8.5 & 9.2 & 10.0 & 10.8 & 8.1 & 8.8 & 9.6 & 10.5 \\
\hline 82.5 & 8.6 & 9.3 & 10.1 & 10.9 & 8.2 & 8.9 & 9.7 & 10.6 \\
\hline 83.0 & 8.7 & 9.4 & 10.2 & 11.0 & 8.3 & 9.0 & 9.8 & 10.7 \\
\hline 83.5 & 8.8 & 9.5 & 10.3 & 11.2 & 8.4 & 9.1 & 9.9 & 10.9 \\
\hline 84.0 & 8.9 & 9.6 & 10.4 & 11.3 & 8.5 & 9.2 & 10.1 & 11.0 \\
\hline 84.5 & 9.0 & 9.7 & 10.5 & 11.4 & 8.6 & 9.3 & 10.2 & 11.1 \\
\hline 85.0 & 9.1 & 9.8 & 10.6 & 11.5 & 8.7 & 9.4 & 10.3 & 11.2 \\
\hline 85.5 & 9.2 & 9.9 & 10.7 & 11.6 & 8.8 & 9.5 & 10.4 & 11.3 \\
\hline 86.0 & 9.3 & 10.0 & 10.8 & 11.7 & 8.9 & 9.7 & 10.5 & 11.5 \\
\hline 86.5 & 9.4 & 10.1 & 11.0 & 11.9 & 9.0 & 9.8 & 10.6 & 11.6 \\
\hline 87.0 & 9.5 & 10.2 & 11.1 & 12.0 & 9.1 & 9.9 & 10.7 & 11.7 \\
\hline 87.5 & 9.6 & 10.4 & 11.2 & 12.1 & 9.2 & 10.0 & 10.9 & 11.8 \\
\hline 88.0 & 9.7 & 10.5 & 11.3 & 12.2 & 9.3 & 10.1 & 11.0 & 12.0 \\
\hline
\end{tabular}


Table 14 Weight-for-length standards (Continued)

\begin{tabular}{|c|c|c|c|c|c|c|c|c|}
\hline 88.5 & 9.8 & 10.6 & 11.4 & 12.4 & 9.4 & 10.2 & 11.1 & 12.1 \\
\hline 89.0 & 9.9 & 10.7 & 11.5 & 12.5 & 9.5 & 10.3 & 11.2 & 12.2 \\
\hline 89.5 & 10.0 & 10.8 & 11.6 & 12.6 & 9.6 & 10.4 & 11.3 & 12.3 \\
\hline 90.0 & 10.1 & 10.9 & 11.8 & 12.7 & 9.7 & 10.5 & 11.4 & 12.5 \\
\hline 90.5 & 10.2 & 11.0 & 11.9 & 12.8 & 9.8 & 10.6 & 11.5 & 12.6 \\
\hline 91.0 & 10.3 & 11.1 & 12.0 & 13.0 & 9.9 & 10.7 & 11.7 & 12.7 \\
\hline 91.5 & 10.4 & 11.2 & 12.1 & 13.1 & 10.0 & 10.8 & 11.8 & 12.8 \\
\hline 92.0 & 10.5 & 11.3 & 12.2 & 13.2 & 10.1 & 10.9 & 11.9 & 13.0 \\
\hline 92.5 & 10.6 & 11.4 & 12.3 & 13.3 & 10.1 & 11.0 & 12.0 & 13.1 \\
\hline 93.0 & 10.7 & 11.5 & 12.4 & 13.4 & 10.2 & 11.1 & 12.1 & 13.2 \\
\hline 93.5 & 10.7 & 11.6 & 12.5 & 13.5 & 10.3 & 11.2 & 12.2 & 13.3 \\
\hline 94.0 & 10.8 & 11.7 & 12.6 & 13.7 & 10.4 & 11.3 & 12.3 & 13.5 \\
\hline 94.5 & 10.9 & 11.8 & 12.7 & 13.8 & 10.5 & 11.4 & 12.4 & 13.6 \\
\hline 95.0 & 11.0 & 11.9 & 12.8 & 13.9 & 10.6 & 11.5 & 12.6 & 13.7 \\
\hline 95.5 & 11.1 & 12.0 & 12.9 & 14.0 & 10.7 & 11.6 & 12.7 & 13.8 \\
\hline 96.0 & 11.2 & 12.1 & 13.1 & 14.1 & 10.8 & 11.7 & 12.8 & 14.0 \\
\hline 96.5 & 11.3 & 12.2 & 13.2 & 14.3 & 10.9 & 11.8 & 12.9 & 14.1 \\
\hline 97.0 & 11.4 & 12.3 & 13.3 & 14.4 & 11.0 & 12.0 & 13.0 & 14.2 \\
\hline 97.5 & 11.5 & 12.4 & 13.4 & 14.5 & 11.1 & 12.1 & 13.1 & 14.4 \\
\hline 98.0 & 11.6 & 12.5 & 13.5 & 14.6 & 11.2 & 12.2 & 13.3 & 14.5 \\
\hline 98.5 & 11.7 & 12.6 & 13.6 & 14.8 & 11.3 & 12.3 & 13.4 & 14.6 \\
\hline 99.0 & 11.8 & 12.7 & 13.7 & 14.9 & 11.4 & 12.4 & 13.5 & 14.8 \\
\hline 99.5 & 11.9 & 12.8 & 13.9 & 15.0 & 11.5 & 12.5 & 13.6 & 14.9 \\
\hline 100.0 & 12.0 & 12.9 & 14.0 & 15.2 & 11.6 & 12.6 & 13.7 & 15.0 \\
\hline 100.5 & 12.1 & 13.0 & 14.1 & 15.3 & 11.7 & 12.7 & 13.9 & 15.2 \\
\hline 101.0 & 12.2 & 13.2 & 14.2 & 15.4 & 11.8 & 12.8 & 14.0 & 15.3 \\
\hline 101.5 & 12.3 & 13.3 & 14.4 & 15.6 & 11.9 & 13.0 & 14.1 & 15.5 \\
\hline 102.0 & 12.4 & 13.4 & 14.5 & 15.7 & 12.0 & 13.1 & 14.3 & 15.6 \\
\hline 102.5 & 12.5 & 13.5 & 14.6 & 15.9 & 12.1 & 13.2 & 14.4 & 15.8 \\
\hline 103.0 & 12.6 & 13.6 & 14.8 & 16.0 & 12.3 & 13.3 & 14.5 & 15.9 \\
\hline 103.5 & 12.7 & 13.7 & 14.9 & 16.2 & 12.4 & 13.5 & 14.7 & 16.1 \\
\hline 104.0 & 12.8 & 13.9 & 15.0 & 16.3 & 12.5 & 13.6 & 14.8 & 16.2 \\
\hline 104.5 & 12.9 & 14.0 & 15.2 & 16.5 & 12.6 & 13.7 & 15.0 & 16.4 \\
\hline 105.0 & 13.0 & 14.1 & 15.3 & 16.6 & 12.7 & 13.8 & 15.1 & 16.5 \\
\hline 105.5 & 13.2 & 14.2 & 15.4 & 16.8 & 12.8 & 14.0 & 15.3 & 16.7 \\
\hline 106.0 & 13.3 & 14.4 & 15.6 & 16.9 & 13.0 & 14.1 & 15.4 & 16.9 \\
\hline 106.5 & 13.4 & 14.5 & 15.7 & 17.1 & 13.1 & 14.3 & 15.6 & 17.1 \\
\hline 107.0 & 13.5 & 14.6 & 15.9 & 17.3 & 13.2 & 14.4 & 15.7 & 17.2 \\
\hline 107.5 & 13.6 & 14.7 & 16.0 & 17.4 & 13.3 & 14.5 & 15.9 & 17.4 \\
\hline 108.0 & 13.7 & 14.9 & 16.2 & 17.6 & 13.5 & 14.7 & 16.0 & 17.6 \\
\hline 108.5 & 13.8 & 15.0 & 16.3 & 17.8 & 13.6 & 14.8 & 16.2 & 17.8 \\
\hline 109.0 & 14.0 & 15.1 & 16.5 & 17.9 & 13.7 & 15.0 & 16.4 & 18.0 \\
\hline 109.5 & 14.1 & 15.3 & 16.6 & 18.1 & 13.9 & 15.1 & 16.5 & 18.1 \\
\hline 110.0 & 14.2 & 15.4 & 16.8 & 18.3 & 14.0 & 15.3 & 16.7 & 18.3 \\
\hline
\end{tabular}


Table 15 Prenatal care coverage Percentage distribution of women aged 15-49 who gave birth in the two years preceding the survey by antenatal care staff, Tunisia, 2011-2012

\begin{tabular}{|c|c|c|c|c|c|c|c|c|}
\hline Tunisia 2011-2012 & & & Doctor & Nurse/Midwife & Auxiliary midwife & $\begin{array}{l}\text { Traditional } \\
\text { accoucheuse }\end{array}$ & $\begin{array}{l}\text { No prenatal } \\
\text { care received }\end{array}$ & Any staff \\
\hline & Total & $\begin{array}{l}1059 \\
100.00\end{array}$ & $\begin{array}{l}837 \\
79.03\end{array}$ & $\begin{array}{l}18 \\
1.69\end{array}$ & $\begin{array}{l}471 \\
44.47\end{array}$ & $\begin{array}{l}1 \\
0.09\end{array}$ & $\begin{array}{l}23 \\
2.17\end{array}$ & $\begin{array}{l}1036 \\
97.83\end{array}$ \\
\hline \multirow[t]{2}{*}{ Gender } & Male & $\begin{array}{l}545 \\
51.46\end{array}$ & $\begin{array}{l}424 \\
77.65\end{array}$ & $\begin{array}{l}7 \\
1.28\end{array}$ & $\begin{array}{l}244 \\
44.77\end{array}$ & $\begin{array}{l}1 \\
0.18\end{array}$ & $\begin{array}{l}16 \\
2.94\end{array}$ & $\begin{array}{l}529 \\
97.06\end{array}$ \\
\hline & Female & $\begin{array}{l}514 \\
48.54\end{array}$ & $\begin{array}{l}413 \\
80.35\end{array}$ & $\begin{array}{l}11 \\
2.14\end{array}$ & $\begin{array}{l}227 \\
44.16\end{array}$ & $\begin{array}{l}0 \\
0.00\end{array}$ & $\begin{array}{l}7 \\
1.36\end{array}$ & $\begin{array}{l}507 \\
98.64\end{array}$ \\
\hline \multirow[t]{2}{*}{ Residence } & Urbain & $\begin{array}{l}601 \\
56.75\end{array}$ & $\begin{array}{l}497 \\
82.69\end{array}$ & $\begin{array}{l}11 \\
1.83\end{array}$ & $\begin{array}{l}244 \\
40.59\end{array}$ & $\begin{array}{l}1 \\
0.16\end{array}$ & $\begin{array}{l}9 \\
1.50\end{array}$ & $\begin{array}{l}592 \\
98.50\end{array}$ \\
\hline & Rural & $\begin{array}{l}458 \\
43.25\end{array}$ & $\begin{array}{l}340 \\
74.23\end{array}$ & $\begin{array}{l}7 \\
1.52\end{array}$ & $\begin{array}{l}227 \\
49.56\end{array}$ & $\begin{array}{l}0 \\
0.00\end{array}$ & $\begin{array}{l}14 \\
3.06\end{array}$ & $\begin{array}{l}444 \\
96.94\end{array}$ \\
\hline \multirow[t]{9}{*}{ Region } & District Tunis & $\begin{array}{l}135 \\
12.75\end{array}$ & $\begin{array}{l}123 \\
91.11\end{array}$ & $\begin{array}{l}0 \\
0.00\end{array}$ & $\begin{array}{l}22 \\
16.29\end{array}$ & $\begin{array}{l}0 \\
0.00\end{array}$ & $\begin{array}{l}3 \\
2.22\end{array}$ & $\begin{array}{l}132 \\
97.78\end{array}$ \\
\hline & Nord Est & $\begin{array}{l}146 \\
13.79\end{array}$ & $\begin{array}{l}130 \\
89.04\end{array}$ & $\begin{array}{l}6 \\
4.10\end{array}$ & $\begin{array}{l}55 \\
37.67\end{array}$ & $\begin{array}{l}0 \\
0.00\end{array}$ & $\begin{array}{l}3 \\
2.05\end{array}$ & $\begin{array}{l}143 \\
97.95\end{array}$ \\
\hline & Nord Ouest & $\begin{array}{l}112 \\
10.58\end{array}$ & $\begin{array}{l}86 \\
76.78\end{array}$ & $\begin{array}{l}1 \\
0.89\end{array}$ & $\begin{array}{l}65 \\
58.03\end{array}$ & $\begin{array}{l}1 \\
0.89\end{array}$ & $\begin{array}{l}1 \\
0.89\end{array}$ & $\begin{array}{l}111 \\
99.11\end{array}$ \\
\hline & Centre Est & $\begin{array}{l}109 \\
10.29\end{array}$ & $\begin{array}{l}102 \\
93.57\end{array}$ & $\begin{array}{l}1 \\
0.91\end{array}$ & $\begin{array}{l}35 \\
32.11\end{array}$ & $\begin{array}{l}0 \\
0.00\end{array}$ & $\begin{array}{l}1 \\
0.92\end{array}$ & $\begin{array}{l}108 \\
99.08\end{array}$ \\
\hline & Kasserine & $\begin{array}{l}102 \\
9.63\end{array}$ & $\begin{array}{l}77 \\
75.49\end{array}$ & $\begin{array}{l}1 \\
0.98\end{array}$ & $\begin{array}{l}54 \\
52.94\end{array}$ & $\begin{array}{l}0 \\
0.00\end{array}$ & $\begin{array}{l}3 \\
2.94\end{array}$ & $\begin{array}{l}99 \\
97.06\end{array}$ \\
\hline & Kairouan & $\begin{array}{l}120 \\
11.33\end{array}$ & $\begin{array}{l}81 \\
67.50\end{array}$ & $\begin{array}{l}0 \\
0.00\end{array}$ & $\begin{array}{l}57 \\
47.50\end{array}$ & $\begin{array}{l}0 \\
0.00\end{array}$ & $\begin{array}{l}2 \\
1.67\end{array}$ & $\begin{array}{l}118 \\
98.33\end{array}$ \\
\hline & Sidi Bouzid & $\begin{array}{l}94 \\
8.88\end{array}$ & $\begin{array}{l}72 \\
76.59\end{array}$ & $\begin{array}{l}1 \\
1.06\end{array}$ & $\begin{array}{l}29 \\
30.85\end{array}$ & $\begin{array}{l}0 \\
0.00\end{array}$ & $\begin{array}{l}10 \\
10.64\end{array}$ & $\begin{array}{l}84 \\
89.36\end{array}$ \\
\hline & South East & $\begin{array}{l}136 \\
12.84\end{array}$ & $\begin{array}{l}94 \\
69.11\end{array}$ & $\begin{array}{l}3 \\
2.20\end{array}$ & $\begin{array}{l}79 \\
58.08\end{array}$ & $\begin{array}{l}0 \\
0.00\end{array}$ & $\begin{array}{l}0 \\
0.00\end{array}$ & $\begin{array}{l}136 \\
100.00\end{array}$ \\
\hline & South west & $\begin{array}{l}105 \\
9.92\end{array}$ & $\begin{array}{l}72 \\
68.57\end{array}$ & $\begin{array}{l}5 \\
4.76\end{array}$ & $\begin{array}{l}75 \\
71.42\end{array}$ & $\begin{array}{l}0 \\
0.00\end{array}$ & $\begin{array}{l}0 \\
0.00\end{array}$ & $\begin{array}{l}105 \\
100.00\end{array}$ \\
\hline \multirow[t]{5}{*}{ Mather's education } & Nothingness & $\begin{array}{l}88 \\
17.46\end{array}$ & $\begin{array}{l}59 \\
67.04\end{array}$ & $\begin{array}{l}0 \\
0.00\end{array}$ & $\begin{array}{l}42 \\
47.72\end{array}$ & $\begin{array}{l}1 \\
1.13\end{array}$ & $\begin{array}{l}2 \\
2.33\end{array}$ & $\begin{array}{l}84 \\
97.67\end{array}$ \\
\hline & Primary and similar & $\begin{array}{l}172 \\
34.13\end{array}$ & $\begin{array}{l}130 \\
75.58\end{array}$ & $\begin{array}{l}1 \\
0.58\end{array}$ & $\begin{array}{l}82 \\
47.67\end{array}$ & $\begin{array}{l}0 \\
0.00\end{array}$ & $\begin{array}{l}3 \\
1.74\end{array}$ & $\begin{array}{l}169 \\
98.26\end{array}$ \\
\hline & $\begin{array}{l}\text { Secondary and } \\
\text { similar }\end{array}$ & $\begin{array}{l}157 \\
31.15\end{array}$ & $\begin{array}{l}125 \\
79.61\end{array}$ & $\begin{array}{l}4 \\
2.54\end{array}$ & $\begin{array}{l}68 \\
43.31\end{array}$ & $\begin{array}{l}0 \\
0.00\end{array}$ & $\begin{array}{l}4 \\
2.55\end{array}$ & $\begin{array}{l}153 \\
97.45\end{array}$ \\
\hline & Superior & $\begin{array}{l}87 \\
17.26\end{array}$ & $\begin{array}{l}81 \\
93.10\end{array}$ & $\begin{array}{l}2 \\
2.29\end{array}$ & $\begin{array}{l}23 \\
27.38\end{array}$ & $\begin{array}{l}0 \\
0.00\end{array}$ & $\begin{array}{l}0 \\
0.00\end{array}$ & $\begin{array}{l}87 \\
100.00\end{array}$ \\
\hline & No reponse & $\begin{array}{l}555 \\
52.40\end{array}$ & $\begin{array}{l}442 \\
79.63\end{array}$ & $\begin{array}{l}11 \\
2.41\end{array}$ & $\begin{array}{l}256 \\
46.12\end{array}$ & $\begin{array}{l}0 \\
0.00\end{array}$ & $\begin{array}{l}12 \\
2.16\end{array}$ & $\begin{array}{l}543 \\
97.84\end{array}$ \\
\hline \multirow[t]{5}{*}{$\begin{array}{l}\text { Annual family incomes } \\
\text { (Economic quintile) }\end{array}$} & The poorest & $\begin{array}{l}288 \\
27.20\end{array}$ & $\begin{array}{l}171 \\
59.37\end{array}$ & $\begin{array}{l}3 \\
1.04\end{array}$ & $\begin{array}{l}151 \\
52.43\end{array}$ & $\begin{array}{l}1 \\
0.34\end{array}$ & $\begin{array}{l}15 \\
5.21\end{array}$ & $\begin{array}{l}273 \\
94.79\end{array}$ \\
\hline & Second & $\begin{array}{l}230 \\
21.72\end{array}$ & $\begin{array}{l}180 \\
78.26\end{array}$ & $\begin{array}{l}5 \\
2.17\end{array}$ & $\begin{array}{l}123 \\
53.47\end{array}$ & $\begin{array}{l}0 \\
0.00\end{array}$ & $\begin{array}{l}2 \\
0.87\end{array}$ & $\begin{array}{l}228 \\
99.13\end{array}$ \\
\hline & Medium & $\begin{array}{l}179 \\
16.90\end{array}$ & $\begin{array}{l}144 \\
80.44\end{array}$ & $\begin{array}{l}2 \\
1.11\end{array}$ & $\begin{array}{l}87 \\
48.60\end{array}$ & $\begin{array}{l}0 \\
0.00\end{array}$ & $\begin{array}{l}5 \\
2.79\end{array}$ & $\begin{array}{l}174 \\
97.21\end{array}$ \\
\hline & Fourth & $\begin{array}{l}221 \\
20.87\end{array}$ & $\begin{array}{l}204 \\
92.30\end{array}$ & $\begin{array}{l}5 \\
2.26\end{array}$ & $\begin{array}{l}80 \\
36.19\end{array}$ & $\begin{array}{l}0 \\
0.00\end{array}$ & $\begin{array}{l}1 \\
0.45\end{array}$ & $\begin{array}{l}220 \\
99.55\end{array}$ \\
\hline & The richest & $\begin{array}{l}141 \\
13.31\end{array}$ & $\begin{array}{l}138 \\
97.87\end{array}$ & $\begin{array}{l}3 \\
2.12\end{array}$ & $\begin{array}{l}30 \\
21.27\end{array}$ & $\begin{array}{l}0 \\
0.00\end{array}$ & $\begin{array}{l}0 \\
0.00\end{array}$ & $\begin{array}{l}141 \\
100.00\end{array}$ \\
\hline
\end{tabular}




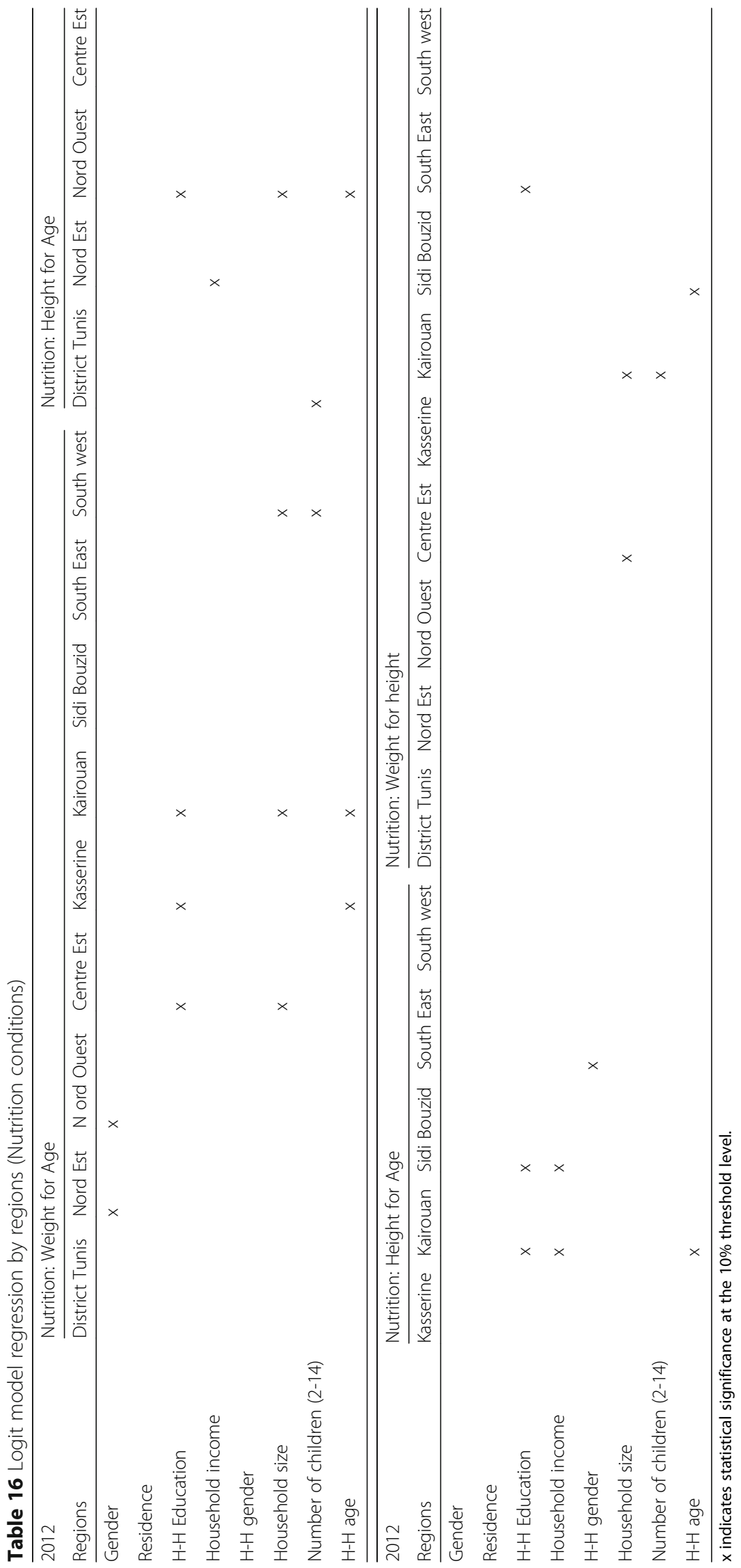




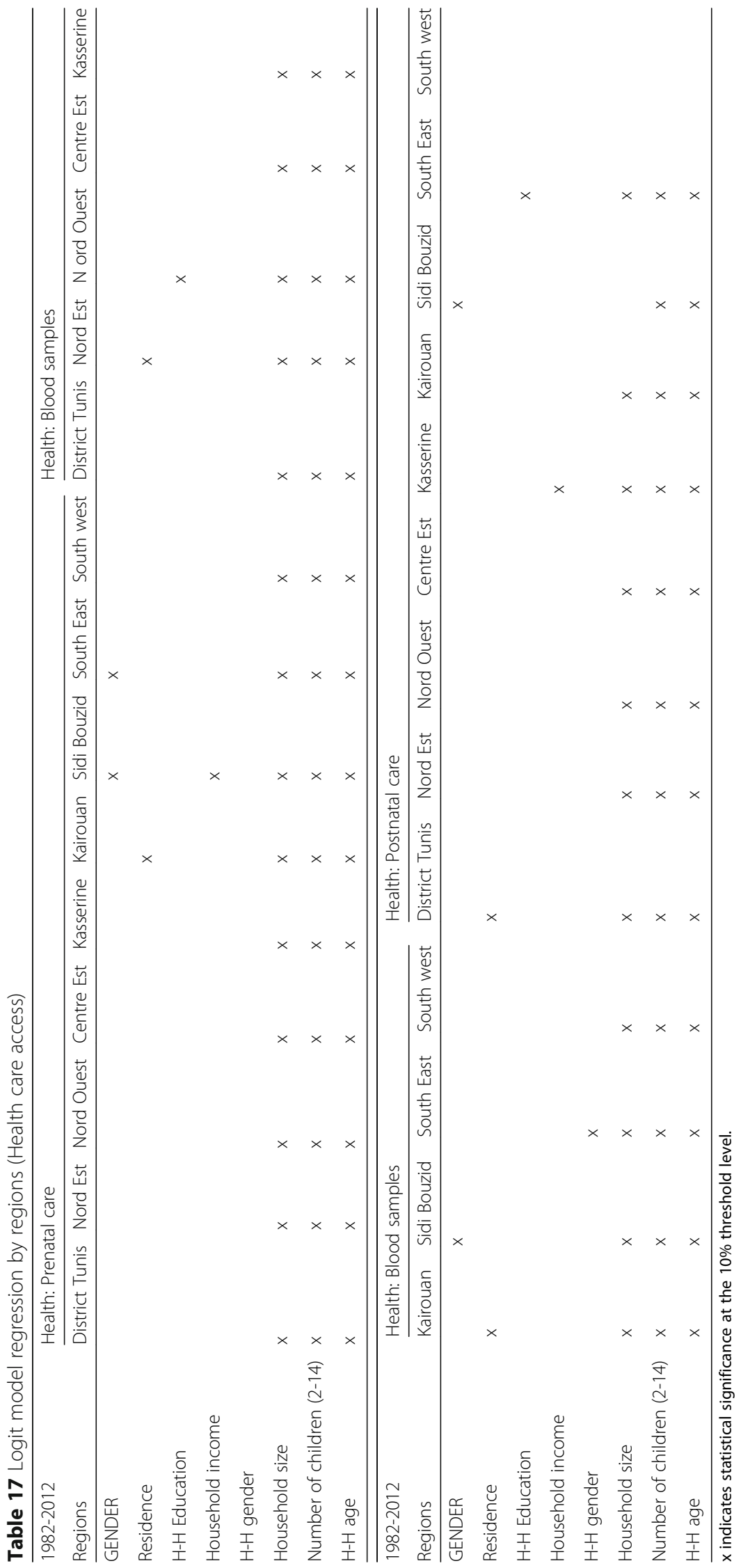




\section{Abbreviations}

HOl: Human opportunity index; INS: National institute of statistics; MICS: Multiple indicator cluster surveys; UNESCO: United Nations, Education, scientific and Cultural Organization; UNFPA: United Nations population fund; UNICEF: United Nations Children's Emergency Fund; WHO: world Health Organization

\section{Acknowledgements}

Not applicable.

\section{Funding}

No funding exist.

\section{Availability of data and materials}

Please contact author for data requests.

\section{Authors' contributions}

Both authors read and approved the final manuscript.

\section{Ethics approval and consent to participate}

Not applicable.

\section{Consent for publication}

Not applicable.

\section{Competing interests}

The authors declare that they have no competing interests.

\section{Publisher's Note}

Springer Nature remains neutral with regard to jurisdictional claims in published maps and institutional affiliations.

\section{Author details}

${ }^{1}$ Faculty of Economic Sciences and Management of Sousse (FSEGSousse), Sousse, Tunisia. ${ }^{2}$ Faculty of Economics Sciences and Management of Tunis (FSEGT), Tunis, Tunisia.

Received: 23 May 2017 Accepted: 2 October 2017

Published online: 25 October 2017

\section{References}

1. Curtale F, Hassanein W, El Wakeel A, Barduagni P, Savioli L. The school health Programme in Behera: an integrated Helminth control Programme at governorate level in Egypt. Acta Trop. 2003:86(2-3):295-307.

2. Roemer J. Equality of opportunity. Cambridge, MA: Harvard University Press; 1998.

3. Bourguignon F, Ferreira $H$, Marta M. Inequality of opportunity in Brazil. Rev Income Wealth. 2007:53(4):585-618.

4. Roemer J. Economic development as opportunity equalization. World Bank Econ Rev. 2014:28(2):189-209.

5. Heckman J. Skill formation and the economics of investing in disadvantaged children. Science. 2006;312(5782):1900-2.

6. Qian M, Wang D, Watkins W, Gebski V, Yan Y, Li M, Chen Z. The effects of iodine on intelligence in children: a meta-analysis of studies conducted in China. Asia Pac J Clin Nutr. 2005;14(1):32-42

7. Glewwe P, Jacoby H, King E. Early childhood nutrition and academic achievement: A Longitudinal Analysis. J Public Econ. 2001;81(3):345-68.

8. Hoddinott J, Maluccio J, Behrman J, Flores R, Martorell R. Effect of a nutrition intervention during early childhood on productivity in Guatemalan adults. Lancet. 2008;371(9610):411-6.

9. UNESCO. Education for all global monitoring report, 2007, strong foundations: early childhood care and education. In: United Nations educational, scientific, and cultural organization. Paris: UNESCO; 2006.

10. Walker S, Wachs T, Gardner J, Lozoff B, Wasserman G, Pollitt E. Child development: risk factors for adverse outcomes in developing countries. International Child Development Steering Group. Lancet. 2007:369:145-57.

11. Barros R, Ferreira H, Molinas Vega J, Chanduvi S. Measuring inequality of opportunity in Latin America and the Caribbean. Washington, DC: The World Bank and Palgrave Macmillan; 2009.

12. De Barros R, Vega J, Saavedra J. Measuring inequality of opportunities for children. Washington, DC: World Bank; 2008
13. Shorrocks A. Decomposition procedures for distributional analysis: a unified framework based on the Shapley value. J Econ Inequal. 2013;11(1):99-126.

14. Rawls. A theory of justice: Oxford University Press; 1971.

15. Sen 1980: Equality of what ?", in McMurrin S. (ed.), Tanner.

16. Dworkin R. What is equality? Part 1: equality of welfare. Philos Public Aff. 1981a:185-246.

17. Dworkin R. What is equality? Part 2: equality of resources. Philos Public Aff 1981b;10(4):283-345.

18. Cohen G. On the currency of egalitarian justice. Ethics. 1989;99:906-44.

19. Arneson R. Equality of opportunity for welfare. Philos Stud. 1989;56(1):77-93.

20. Roemer J. A pragmatic theory of responsibility for the egalitarian planner. Philos Public Aff. 1993;22:146-66.

21. Ferreira F, Gignoux J. The measurement of inequality of opportunity: theory and an application to Latin America. Rev Income Wealth. 2011;57(4):622-57.

22. Sen A. Real National Income. Rev Econ Stud. 1976:43(1):19-39.

23. De Barros R. Measuring inequality of opportunity in Latin America and the Caribbean: World Bank Publications; 2009.

24. INS. 2010. The National Survey on Households' Budget, Consumption and Standard of Living www.ins.nat.tn.

25. UNICEF. The State of the world's children 2009 maternal and newborn health. New York: UNICEF; 2008.

26. World Health Organization. Making pregnancy safer: The Critical Role of the Skilled Attendant. In: A joint statement by WHO, ICM and FIGO. Geneva, Switzerland: World Health Organization; 2004.

27. Son H. Inequality of human opportunities in developing Asia. Asian Dev Rev. 2013;30(2):328.

28. Chantreuil F, Trannoy A. Inequality decomposition values: the trade-off between marginality and efficiency, the journal of economic inequality. Springer; Soc Stud Econ Inequality. 2013;11(1):83-98

29. Sastre $M$, Trannoy A. Shapley inequality decomposition by factor components: some methodological issues. J Econ. 2002;77(1):51-89. Springer

30. Dercon S, Sanchez A. Long-term implications of under-nutrition on psychosocial competencies: evidence from four developing countries. In: Young lives working paper no. 72. Oxford, UK; 2011.

31. Glewwe P. Miguel E. The impact of child health and nutrition on education in less developed Countries. In: Handbook of Development Economics, vol. 4; 2008. p. 3564-606.

32. Helmers C, Patnam M. The formation and evolution of childhood skill acquisition: evidence from India J Dev Econ. 2011:95(2):252-66.

\section{Submit your next manuscript to BioMed Central and we will help you at every step:}

- We accept pre-submission inquiries

- Our selector tool helps you to find the most relevant journal

- We provide round the clock customer support

- Convenient online submission

- Thorough peer review

- Inclusion in PubMed and all major indexing services

- Maximum visibility for your research

Submit your manuscript at www.biomedcentral.com/submit
Biomed Central 